\title{
İlkokul Çağı Öğrencilerinin Ders Çalışma Sürecinde Teknolojik Araç Kullanımına İlişkin Veli Görüșleri
}

\author{
İbrahim Fidan ${ }^{1 *}$ \\ Dr. Öğr. Üyesi Feti Çelik ${ }^{2}$
}

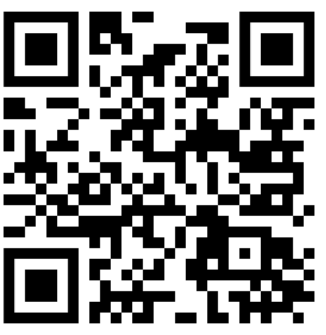

Geliş tarihi: 02.11.2020

Kabul tarihi: 24.11.2020

\section{Atıf bilgisi:}

IBAD Sosyal Bilimler Dergisi

Sayı: Özel Sayı Sayfa: 484-512

Yıl: 2020

This article was checked by Turnitin. Similarity Index 23\%

Bu makalede araştırma ve yayın etiğine uyulmuştur.

${ }^{1}$ Burdur Mehmet Akif Ersoy Üniversitesi, Türkiye,

ibrahimfidan199215@hotmail.com, ORCID ID 0000-0002-4487-4792

${ }^{2}$ Burdur Mehmet Akif Ersoy Üniversitesi, Türkiye, fcelik@mehmetakif.edu.tr, ORCID ID 0000-0002-9883-8922

* Sorumlu yazar
ÖZ

$\mathrm{Bu}$ araştırmanın amacı, ilkokul çağı öğrencilerinin derslerinde Teknolojik Araç (TA bilgisayar, telefon, tablet ve televizyon) kullanımına ilişkin veli görüşlerini velilerin; cinsiyeti, yaş aralığı, öğrenim düzeyi, evde kullanılan Teknolojik Araç (TA) sayısı, öğrencilerin; sınıf düzeyleri, TA kullanım süresi, evde internet bağlantısı değişkenlerine göre farklılaşma olma durumunu incelemektir. Araştırma betimsel nitelikte bir alan araştırması olup tarama modeli kullanılmıştır. Araştırma evrenini Burdur ili Bucak ilçe merkezinde öğrenim gören bütün ilkokul öğrenci velileri oluşturmaktadır. Araștırma verileri, Burdur İl Milli Eğitim Müdürlüğü ile iletișim kurularak olasılık temelli örnekleme yöntemlerinden rastlantısal kümeleme yöntemi kullanılarak toplanmıştır. Araştırmanın verilerini 2017-2018 eğitim-öğretim yılında Burdur ili Bucak ilçesinde sekiz ilkokul ve bir özel ilkokulda öğrenim gören 418 öğrencinin velileri oluşturmaktadır. Araştırmanın verileri, araştırmacı tarafindan uyarlanan "İlkokul Çağı Öğrencilerinin Ders Çalışma Sürecinde Teknolojik Araç Kullanımına İlişkin Veli Görüşleri” ölçeği ile toplanmıştır. Çalışma ölçeğinin Cronbach's alpha güvenirlik katsayısı ,78 olarak hesaplanmıştır. Verilerin analizi, SPSS 22 programı kullanılarak yapılmıştır. Verilerin analiz edilmesinde frekans, yüzde, aritmetik ortalama, standart sapma, Mann Whitney U Testi, Kruskal Wallis Testi kullanılmıştır. Çalışma sonucunda, velilerin ilkokul öğrencilerinin Teknolojik Araç (TA) ile zaman geçirirken aile rehberliğini önemsedikleri görülmüştür. Velilerin, öğrencilerin sıklıkla TA kullanımlarının beden sağlığı, arkadaşlık iliş̧kileri, ders başarıları ve sosyal iletişim becerilerini olumsuz etkilediğini düşündükleri saptanmıştır.

Anahtar Kelimeler: Ders Çalışma Süreci, İlkokul Çağı, Teknolojik Araç Kullanımı. 


\title{
Parents' Views Regarding the Use of Technological Tools in the Study Process of Primary School Students
}

\author{
İbrahim Fidan ${ }^{1^{*}}$ \\ Dr. Öğr. Üyesi Feti Çelik ${ }^{2}$
}

First received: 02.11 .2020

Accepted: 24.11.2020

\section{Citation:}

IBAD Journal of Social Sciences

Issue: Special Issue $\quad$ Pages: 484-512

Year: 2020

This article was checked by Turnitin. Similarity Index 23\%

${ }^{1}$ Burdur Mehmet Akif Ersoy University, Turkey,

ibrahimfidan199215@hotmail.com, ORCID ID 0000-0002-4487-4792

2 Burdur Mehmet Akif Ersoy University, Turkey, fcelik@mehmetakif.edu.tr, ORCID ID 0000-0002-9883-8922

\footnotetext{
* Corresponding Author
}

\begin{abstract}
The aim of this study is to examine the parents 'views on the use of Technological Tools (TA: computer, phone, tablet and television) in primary school students' lessons; gender, age range, education level, number of Technological Tools (TA) used at home, students; to examine the differentiation according to grade levels, duration of TA usage, and home internet connection variables. The research is a descriptive field study and a survey model has been used. The universe of the research consists of parents of all primary school students studying in Bucak district center of Burdur province. The research data were collected using the random clustering method, one of the probabilistic sampling methods, by contacting the Burdur Provincial Directorate of National Education. The data of the research are composed of the parents of 418 students studying at eight primary schools and one private primary school in Bucak district of Burdur province in the 2017-2018 academic year. The data of the research were collected with the "Parents' Opinions on the Use of Technological Tools in the Study Process of Primary School Students" adapted by the researcher. Cronbach's alpha reliability coefficient of the working scale was calculated as 78. Data analysis was done using SPSS 22 program. Frequency, percentage, arithmetic mean, standard deviation, Mann Whitney U Test, Kruskal Wallis Test were used to analyze the data. As a result of the study, it was observed that parents care about family guidance while spending time with the Technological Tool (TA) of primary school students. It was found that the parents thought that the frequent use of TA of the students negatively affected their physical health, friendship relations, course success and social communication skills.
\end{abstract}

Keywords: Study Process, Primary School Age, Technological Vehicle Use. 


\section{GİRIŞ}

Okula yeni başlayan öğrenciler heyecan, coşku ve merak duygusu içindedirler. Merak duyguları ilkokul birinci sınıf öğrencilerinde ise en üst düzeye çıkabilmektedir. Okul ortamında farklı sınıf düzeylerinin ve farklı ders gruplarının olduğunun bilinci ilk olarak ilkokul birinci sınıf öğrencilerinde oluşur. Böyle farklı durumlar ile karşılaşan ilkokul öğrencileri üzerinde bu durumun etkileri üst düzeyde görülmektedir. İlkokul dönemi, öğrencilerin anne ve babaları ile ders çalışma sürecinde etkileşimin başlangıcı olarak kabul edebileceğimiz bir zaman dilimine denk gelmektedir. Özellikle ders çalışma süreci ve alışkanlıklarının belirlenmesinde ilkokul çağı başlangıç olarak kabul görmektedir. Ders çalışma süreci ise evde yapılan ödev ve araştırmaları içine alır. Öğrenciler erken yaşlarda Teknolojik Araçlar (TA: bilgisayar, telefon, tablet ve televizyon) ile vakit geçirmektedir. Bu durum ise TA'ların öğrencileri gerçek oyun kültüründen alıkoyarak kendileri için henüz çok erken olan bir dönemde kaldırabileceklerinin üzerinde miktarda uyarana maruz bırakabileceği tehlikesi söz konusudur. $\mathrm{Bu}$ Teknolojik Araç (TA)'lar ile sağlanan sanal dünyanın gerçeği yansıtmaktan uzak olması, öğrenciyi gerçeklerden izole bir yaşama doğru çekmesi, farkındalığını ve yaratıcılığını azaltması gibi eleştiriler dile getirilen görüşler arasındadır (Akbulut, 2013).

Teknolojik araçların (TA) eğitimde kullanılması alışılagelmiş öğretim yöntemlerine nazaran öğrencilerin daha uzun dinlemelerine ve derinlemesine konuyu kavramalarına ortam hazırlayıp firsat vermektedir. Ayrıca eğitimde TA kullanımıyla bireyler içselleştirilmiş bilginin yanında, bu bilginin nasıl ve nerede kullanılacağı hususunda yeterlilikte kazanmaktadırlar (Kenar, 2012). Bilgi arama ve okul ile ilgili faaliyetlerde TA'ları işe koşma şeklinde betimlenen kullanım amaçlarının ikinci planda kalabildiği, TA'ların daha çok güncel gelişme ve dedikodulardan haberdar olmak, müzik dinlemek, oyun oynamak, sohbet etmek, dosya indirmek, eğlenmek ve benzeri amaçlar için kullanıldığı gözlemlenmektedir (Bayraktar ve Gün, 2007).

Öğrencilerin TA kullanımının fiziksel, bilişsel ve psikososyal sonuçları hakkında daha bilinçli olmamız gerekmektedir. TA'ların uzun süreli kullanımı bir takım fizyolojik sorunlara sebep olabilmektedir. Gelişim döngüsünü tamamlamamış olan öğrencilerde bu fizyolojik problemler çok daha ciddi boyutlarda yaşanabilmektedir. Özellikle uzun süreli TA kullanımı, oturuş bozuklukları nedeniyle kas ve iskelet sistemi rahatsızlıklarının gözlemlenmesi, vücutta gerginlik ve tutulma yaşanması sıklıkla rastlanan bir durumdur. Ayrıca göz yorgunluğu, gözde ağrı ya da acıma, kuruluk ve benzeri rahatsızlıklar görülebilmektedir. Bunun dışında TA'lardan yayılan radyasyon dalgalarının öğrencileri yetişkinlere nazaran daha ciddi bir biçimde etkilemesi söz konusudur (Akbulut, 2013).

Öğrencilerin karakterinin şekillendiği, bireylerle uyum içerisinde olabilme becerisinin kazanıldığı olumlu veya olumsuz etkilerin yansıdığı ilk çevre ailedir. Aile, ilkokul öğrencilerinin yoğun şekilde etkileşim halinde olduğu gelişim, davranış ve öğrenme adına etkinliklerin yapıldığı en temel ortamdır. $\mathrm{Bu}$ yüzden aile, öğrencilerin davranış becerilerinde ve eğitimlerinde öncelikli bilgilerin edinildiği ortamdır. Bu ortamda aileler öğrencilerin eğitiminden ve gelişiminden sorumlu hale gelmektedir (Çamlıbel Çakmak, 2010).

Özellikle sosyalleşme yetileri bağlamında TA kullanımının birey üzerindeki etkileri hakkında yapılmış araştırmalara sıklıkla rastlamak olanaklıdır. Ülkemizde bu araştırmalardan bir tanesi 2008 yılında tamamlanmıştır (Kuzu, 2008). Araştırmada en sık rapor edilen sorunlardan bir tanesinin mesajlaşma programı açık olmadığı zamanlarda bireyi kendisini huzursuz hissetmesi olduğu ortaya konmaktadır. Ayrıca TA kullanımına bağlı olarak öğrencilerin babalardan, babaların ise annelerden daha sık psikososyal sorun yaşadığı görülmektedir. Aile bireylerinin TA kullanım süreleri arttıkça, yaşanan psikososyal sorunlarında arttı̆̆ gözlemlenmiş; öğrencilerde yetişkinlere göre daha ciddi sorunlar yaşandığı ortaya konmuştur. Araştırmanın ciddi bulgularından bir tanesi aile bireylerinin çoğunlukla TA kullanımına bağlı olarak ortaya çıkabilecek psikososyal sorunlara ilişkin çok az bilgi sahibi olmalarıdır.

Türkiye İstatistik Kurumu (TÜIK), verilerine göre, 2016 yılı Nisan ayında hanelerin \%96,9'unda cep telefonu veya ak1llı telefon, \%22,9'unda masaüstü bilgisayar, \%66'sında taşınabilir bilgisayar bulunmaktadır. $\mathrm{Bu}$ yoğunlukta kullanılan TA'ların kullanımının araştırma sorgulama becerilerini geliştirmeye yönelik olması gerekir. Çağın gerektirdiği değişim ve gelişimlere ayak uydurmak için insanların TA kullanımı gün geçtikçe artmaktadır. Bir toplumun gelişmişlik düzeyine günümüzde 
doğrudan etkisi olan TA’lar, her alanda etkisini hissedilir derecede göstermektedir. TA kullanımının yaygınlaşması eğitim alanını etkilemektedir (Özçiftçi ve Çakır, 2015). Günümüzde toplumsal yaşamın bir parçası durumuna gelen TA'lar, ortam olarak içinde birçok araç bulundurmaktadır. $\mathrm{Bu}$ araçların toplumsal yaşamda kullanılan araçlara olan benzerliği ve kullanım kolaylığı nedeniyle, TA kullanımı hızla yaygınlaşmıştır. Başaran'a (2005) göre, öğrenciler farklı ders çalışma becerisine sahiptir. Bu beceri içerisine, öğrencilerin okul hayatı ve ders çalışma becerileri ile gözlenebilen ve gözlenemeyen davranışların tümü; ders çalışırken ve ders dinlerken hissettikleri, öğretmene ve derse karşı ilgi düzeyleri ve tutumları, ders çalışma yöntemleri, ders çalışma ortamlarının düzenlenmesi ve sınava hazırlanma süreçleri girmektedir. Öğrenmeyi kişinin kendisinin öğrenmesi, insanın kendini saran durumları, değerleri becerileri, problem çözmeyi öğrenmesidir. Bunu sağlamak için insan denemelere girişir, sorular sorar, araştırır, inceler, gözlem yapar, bilenlerle görüşür ve okur (Demirezen ve Akhan, 2012). TA gelişiminin hızlı bir şekilde ilerlediği dünyada, insanların ihtiyaçları büyük ölçüde değişmektedir (Avcı ve Nazlı, 2005). Küçükahmet'e (2009) göre, ders çalışma becerileri, öğrencilerin okulda geçirdikleri zaman ile çevrede geçirilen zamanlarda edilen bilgi ve davranışların hayata yansıması şeklindedir. Ders çalışma becerilerini bilgisayar, telefon, tablet ve televizyon gibi sık kullanılan TA'lar yönlendirmekte ve etkilemektedir.

TA'ları doğru şekilde, doğru miktarda kullanmak elbette zararlı değil, yararlı bir kullanım olmaktadır. Öğrencilerin zekâ oyun becerilerini geliştirmeye yönelik çok özel oyunlara (egzersizler) TA'lar ile kolayca ulaşılabilmektedir. TA başında çok fazla oyun oynayan öğrencilerin, gerçek hayattan kopuk olduğu görülmekte ve bu süreç boyunca sosyal becerileri zayıflamaktadır. Öğrenciler, bir oyunda elde ettiği kıdemi, ulaştığı seviyeyi bir saygınlık unsuru olarak görebilmekte ve arkadaş çevresinde bu özellikleriyle saygınlık kazanmaya çalışmaktadır (Beder, 2015).

Velileri tarafindan, öğrenciye daima TA sunulmayacağına ve bunun zaten yanlış olduğu bilindiğine göre çeşitli kısıtlamalara gidilmesi kaçınılmazdır. Ancak bu kısıtlamalar için gecikmiş olunmasından dolayı öğrencinin, mutsuz bir öğrenciye dönüşmesine sebep olunmaktadır. Bağımlı1ıktan anlaşılan TA'ların bilinçli ve kontrollü kullanılmaması durumunda TA'ların zararlarının katlanarak artmasıdır. Böylelikle öğrencilerde TA bağımlılığı sorunu meydana gelir (Sünbül, 2008). Öğrencilerin gelişimi açısından aile ile beraber geçirdikleri hayatlarının ilk yılları çok önemlidir. İlk yıllarda kazanılan beceri, tutum, kazanım ve alışkanlıklar ilerleyen yıllarda öğrencilerin yaşantılarını etkilediği görülmektedir (Akpınar, 2005). TA kullanımının öğrenciler üzerinde etkisi oldukça fazla düzeyde olmaktadır. Bu etkileşimin olumlu şekilde olması öğrenci başarısını doğrudan etkilemektedir. Bu yüzden öğrenciler için tavsiye edilen günlük TA kullanım sürelerine uyulursa TA'lar yararlı; uyulmazsa zararlıdır. Bu durumlar öğrencilerin zeka katsayısında (IQ) artış1 etkilemektedir (Ata, Altun, Avc1, Er ve Öztürk, 2010).

Öğrenciler, bazı riskleri öngörememektedirler. Hangi uygulamaların faydalı, hangi uygulamaların zararlı olduğu konusunda velileri tarafindan öğrencilere rehberlik yapılması gerekliliği unutulmamalıdır. $\mathrm{Bu}$ durumlar, öğrencilerin eğitici ve öğretici içerik zenginliğini etkilemektedir (Aslanargun, 2007). Kendini tamamlama duygusuna erişen öğrenciler ilkokul döneminden itibaren çok daha üretken hale gelmektedir. Aynı zamanda duygusal gelişim açısından oldukça önemli bir beceri bütünü haline gelmektedir. $\mathrm{Bu}$ durumların, öğrencilerin yaratıcılık becerilerini etkilemektedir (Aktay ve Güven Aktay, 2015). Teknolojik Araçlar (TA)'lar insan yaşamını önemli ölçüde etkilemiştir. TA'lar, öğretimde yardımcı bir rol üstlenmeli fakat öğretimin amacı haline getirilmemelidir. TA'ları sadece var olduğu için kullanmaya çalışılmamalı veya TA'lar kullanılmadığında çağ dışı kalınacakmış gibi bir korkuya kapınılmamalıdır (Alpar, Batdal ve Avc1, 2007).

6-15 yaş grubunun neredeyse yarısının her gün TA kullandığını, erkeklerin $\% 48$ ile $\% 43$ oranına sahip kızlara göre biraz daha sık internet kullandığ 1 görülmektedir. Bu yaş grubundakilerin \%90'ınından fazlası her gün veya haftada en az bir kez TA kullanmaktadır. Ayda en az bir defa veya ayda bir defadan az diyenlerin oranı ortalama $\% 8$ oranındadır. Haftalık kullanım sürelerine bakıldığında 6-15 yaş grubunun neredeyse yarısı haftada 3-10 saat TA ile vakit geçirmektedir. $\mathrm{Bu}$ yaş grubunda erkeklerin daha fazla TA ile vakit geçirdiği söylenebilir. 6-15 yaş grubu öğrencilerin TA kullanım amaçlarına bakıldığında ödev yapma veya öğrenme amacıyla TA'lara başvurmanın \%85 ile ilk sırada yer aldığını, sonra sırasıyla \%79 ile oyun oynama ve \%57 ile bilgi arama amaçlarının geldiği görülmektedir (Güler, Şahinkayası ve Şahinkayası, 2017). Verimli TA kullanımı sayesinde öğrencilerin fikirlerini 
deneyebilecekleri bir ortama da kavuşmuş olacaklardır. TA'lar sayesinde üretilen her düşünce geniş bir kesime ulaşabilir olmaktadır. Böylelikle ortaya çıkarılan her üretken düşünce kısa sürede gönderilebilir, tartış1labilir ve bir an önce işe koşulabilir hale gelmiştir (Şimşek, 2002). TA'ların bilinçli kullanım eğitimi önemle çalışılması gereken konulardan biridir. Bilgisayar, telefon, tablet ve TV'lerin işlevleri giderek artmakta ve ders çalışma süreçleri ile birlikte eğitimin toplumsal değişimini etkilemektedir. TA'larda değişimin yaşamın diğer alanları ile birlikte öğrencilerin ders çalışma süreçlerini de etkilemesi kaçınılmazdır (Seferoğlu, 2008). Ders çalışma süreçlerinde TA kullanımını sağlayabilen öğrenciler ögrenmiş oldukları araştırma, sorgulama becerileri sayesinde derslerinde olumlu yansımalarını görmektedir. (Ata, Altun, Avc1, Er ve Öztürk, 2010).

Sakarya, Tercan ve Çoklar (2011), tarafindan yapılan çalışmada, öğrencilerin bilgi kaynağ olarak kullandıkları en önemli kaynağın internetin olduğu ve ders kitabı, çalışma kitabı, ansiklopedi gibi kaynaklardan çok daha öncelikli bir yer edindiği görülmüsştür. İlkokul öğrencilerinin büyük bölümünün interneti; bilgi aramak, oyun oynamak, haberleşmek, film izlemek, müzik dinlemek, haber takip etmek gibi nedenlerle kullandığı görülmüştür. Eğitimde öğretmenlerin görevi, öğrencileri hayata en hazır halde yetiştirerek bırakmaktır. Özellikle günümüzde öğrencilerin donanımlı ve problem çözme becerilerinin üst düzeyde olması beklenmektedir. Bu durum öğrencilerin TA kullanma becerilerinin olması ile mümkündür (Karaman ve Kurfallı, 2008). Özellikle ilkokul öğrencilerinin TA'ları kullanırken yaşayabilecekleri birçok tehlike bulunmaktadır. Öğrenciler, zararlı yazılım ve TA’lar üzerinden tehlikelere maruz kalabilmektedir (Odabaşı, Kabakçı ve Çoklar, 2007).

Kayıran'a (2010) göre, internet öğrencilere araştırma becerisi kazanmanın yanında bilgisayar oyunlarıyla öğrencilerin eğlenmesine yardımcı olmaktadır. İnternetin olumsuzluklarından öğrenci ve ergenleri korumak için öğrenciler ile velilerin bilgisayar oyunlarını birlikte oynaması gerektiğini ortaya koymuştur. Oynanan oyunların öğrencilere kişilik katkılarının olup olmadığı veliler ile birlikte değerlendirilmelidir. Toplumumuzda işin kolayına kaçmadan sorunların belirlenmesi gerekir. Bu şekilde uygulamaların nadirliği, üzerinde durulması gereken sosyolojik sorunların en önemlilerinden biridir (Ayhan, 2008). TA kullanımının beceri eğitiminin ilkokullarda doğru bir biçimde verilebilmesi, sınıfla etkinliklerin belli ölçütlerle yapılması için öğretmenlerin ve velilerin gerekli özeni göstermeleri oldukça önemlidir (Aktay ve Güven Aktay, 2015).

Bu çalışmanın amacı, velilerin ilkokul çağı öğrencilerinin ders çalışma sürecinde Teknolojik Araç (TA) kullanımına ilişkin görüşlerinde velilerin; cinsiyeti, yaş aralığı, öğrenim düzeyi, evde kullanılan TA sayısı, öğrencilerin; sınıf düzeyleri, TA kullanım süresi, evde internet bağlantısında farklılaşma durumunu incelemektir. Teknolojik Araç (TA)'ların ders çalışma süreçlerinde verimli ve etkin kullanımı ilkokul döneminde çok önemlidir. TA'ların öğrencilerin yaşamlarında büyük rolü olduğu bilinmektedir. Bu etkilerin nasıl ve ne yöne doğru ilerlediği önem arz etmektedir. Öğrencilerin ilk eğitim aldıkları yer olan aile kurumunun olduğu bilinmektedir. Velilerin, TA kullanımı konusunda öğrencilere doğru yönlendirmeyi yapıyor olması beklenmektedir. TA kullanma becerisi özellikle öğrencilerin okumayı öğrendiği ilkokul çağında öğrencileri üst düzeyde etkilemektedir. Bu yüzden öğrencilerin TA'ları nerelerde ve nasıl kullanması gerektiğini bilmesi, öğrencilerin TA'ları doğru kullanıp bilgiye hızlı ulaşma ve fikirler üretme noktasında ders çalışma süreçlerinde kullanmalarına yararlı olacaktır.

İlkokul çağı öğrenci velileriyle bu araştırmayı yaparak ihtiyacın giderilebileceği düşünülmektedir. $\mathrm{Bu}$ çalışmayla ilkokul çağı öğrencilerinin ders çalışma sürecinde TA kullanımında veli görüşlerini çeşitli değişkenlere göre inceleyip nasıl olduğu ortaya konulacaktır. Böylelikle ilkokul çağı öğrencilerinin TA'ları daha çok ne amaç doğrultusunda kullandığı ile veli görüşlerinin ilişkisini belirleyip bu konuda farkındalıkları arttırılmaya çalışılacaktır.

İlkokul çağı öğrencilerinin ders çalışma sürecinde TA (Teknolojik Araç; bilgisayar, telefon, tablet ve televizyon) kullanımlarının veli görüşleri dağılımına göre;

- Veli madde ortalama puanları nasıldır?

- Veli cinsiyetine göre anlamlı bir fark göstermekte midir?

- Veli yaş aralığına göre anlamlı bir fark göstermekte midir?

- Veli öğrenim düzeyine göre anlamlı bir fark göstermekte midir?

IBAD Sosyal Bilimler Dergisi / IBAD Journal of Social Sciences, (Özel Sayı/Special Issue), 2020 
- Evde kullanılan Teknolojik Araç (TA) sayısına göre anlamlı bir fark göstermekte midir?

- Öğrencilerin sınıf düzeyine göre anlamlı bir fark göstermekte midir?

- Öğrencilerin TA kullanım süresine göre anlamlı bir fark göstermekte midir?

- Evde internet bağlantısı olma durumlarına göre anlamlı bir fark göstermekte midir?

\section{YÖNTEM}

\section{Araştırmanın Modeli}

Araştırma betimsel nitelikte bir alan araştırması olup tarama modeli kullanılmıştır. Bu araştırma ilkokul çağı öğrencilerinin ders çalışma sürecinde TA kullanımında veli görüşlerini belirlemeye yönelik olarak çalışıldığından tarama modeli kullanılmıştır. Tarama modelleri, geçmişte ya da olan bir durumu olduğu şekliyle tasvir etmeyi amaçlayan (Karasar, 2000) ve bir konuya ya da olaya ilişkin katılımcı görüşlerinin ilgi, beceri, yetenek, tutum vb. özelliklerinin belirlendiği genellikle diğer araştırmalara göre daha büyük örneklemler üzerinde yapılan araştırmalardır (Büyüköztürk, Kılıç Çakmak, Akgün, Karadeniz ve Demirel, 2008).

\section{Evren ve Örneklem}

Evren, araştırma sonuçlarının genellenmek istendiği elemanlar bütünüdür. Evren, soyut bir kavramdır; tanımlanması kolaydır fakat ulaşılması güçtür ve hatta çoğu zaman olanaksız bir bütündür. Bu nedenle, araştırmalarda kullanılan "evren" terimini "çalışma evreni”" olarak algılamak gerekir (Karasar, 2017). Örneklem ise çalışma evreninin büyüklüğü ya da çokluğu sebebiyle bütün elemanlara ulaşma imkânı olmadığı zamanlarda çalışma evrenini temsilen çalışma evreni içinden seçilen gruplara denir (Cebeci, 2014; Balc1, 2015). Araştırma verileri, olasılık temelli örnekleme yöntemlerinden rastlantısal kümeleme yöntemi kullanılarak toplanmıştır. Bu çalışmanın evrenini Burdur ili Bucak ilçe merkezinde ilkokulda öğrenim gören 2118 öğrencinin velileri, örneklemini ise Burdur ili Bucak ilçe merkezinde bulunan sekiz ilkokul ve bir özel ilkokulda öğrenim gören 418 öğrencinin velileri oluşturmaktadır. Örneklem araştırmacının yaşadığı yere ve görev yaptığı okula yakın olması nedeniyle kolay ulaşılabilir niteliktedir. Çalışmada toplamda 418 veliden elde edilen veriler kullanılmıştır. Tablo 1'de araştırmaya katılan velilerin ve öğrencilerin demografik özellikleri verilmiştir.

Tablo 1. Araştırmaya Katılan Velilerin ve Öğrencilerin Demografik Özellikleri

\begin{tabular}{|c|c|c|c|}
\hline \multicolumn{2}{|c|}{ Demografik Özellikler } & $\mathrm{N}$ & Yüzde (\%) \\
\hline & Kadın & 282 & 68 \\
\hline \multirow[t]{2}{*}{ Veli Cinsiyet } & Erkek & 126 & 30 \\
\hline & Toplam & 408 & 98 \\
\hline \multirow{4}{*}{ Yaş Aralıkları } & 35 Ve Alt1 & 189 & 45 \\
\hline & $36-45$ & 189 & 45 \\
\hline & 46 Ve Üstü & 16 & 4 \\
\hline & Toplam & 394 & 94 \\
\hline \multirow{6}{*}{ Öğrenim Durumu } & İlkokul & 108 & 26 \\
\hline & Ortaokul & 68 & 16 \\
\hline & Lise & 125 & 30 \\
\hline & Üniversite & 96 & 23 \\
\hline & Lisansüstü & 15 & 4 \\
\hline & Toplam & 412 & 99 \\
\hline \multirow{5}{*}{ Öğrenci Sınıf Düzeyleri } & 1.sinif & 73 & 17 \\
\hline & 2.sinif & 113 & 27 \\
\hline & 3.sinif & 85 & 20 \\
\hline & 4.sinif & 121 & 29 \\
\hline & Toplam & 392 & 93 \\
\hline \multirow{7}{*}{ Öğrenci TA Kullanım Süresi } & Hiç & 120 & 29 \\
\hline & 1 Yildan Az & 23 & 6 \\
\hline & $1 Y_{11}$ & 12 & 3 \\
\hline & $2 Y_{11}$ & 10 & 2 \\
\hline & $3 Y_{11}$ & 14 & 3 \\
\hline & 3 Yildan Fazla & 222 & 53 \\
\hline & Toplam & 401 & 96 \\
\hline \multirow{5}{*}{ TA Sayıs1 } & 1 Adet & 102 & 25 \\
\hline & 2 Adet & 154 & 37 \\
\hline & 3 Adet & 122 & 30 \\
\hline & 4 Adet & 30 & 7 \\
\hline & Toplam & 418 & 100 \\
\hline
\end{tabular}




$\begin{array}{lccc} & \text { Var } & 195 & 47 \\ \text { Internet Bağlantısı } & \text { Yok } & 147 & 35 \\ & \text { Toplam } & 342 & 82\end{array}$

Katılımcıların demografik özelliklerini gösteren Tablo 1 incelendiğinde, katılımcıların 282'si (\%68) kadın, 126'sı (\%30) erkeklerden oluşmaktadır. Katılımcıların 45 yaş ve altı 378 kişi (\%90) oluşturmaktadır. Velilerin 108'inin (\%26) ilkokul mezunu, 68'inin (\%16) ortaokul mezunu, 125'sinin (\%30) lise mezunu, 96'sının (\%23) üniversite mezunu ve 15'inin (\%4) lisansüstü mezunu olduğu tespit edilmiştir. Katılımcıların evlerinde bulunan TA sayısı incelendiğinde evlerde 102'sinin (\%24) bir adet, 154'ünün (\%35) iki adet, 122'sinin (\%29) üç adet ve 30'unun (\%7) dört adet TA sayısına sahip olduğu tespit edilmiştir. Katılımcı öğrencilerinin 73’ü (\%17) birinci sınıf, 113’ü (\%27) ikinci sınıf, 85’i (\%20) üçüncü sınıf, 121'i (\%29) dördüncü sınıf olarak belirlenmiştir. Katılımcı öğrencilerinin çoğunluğunun üç yıldan fazla bilgisayar kullanma tecrübesi olduğu 222 (\%52) tespit edilmiştir. Velilerin 195 (\%47) kişinin evlerinde internet erişimi olduğu görülmüştür.

\section{Veri Toplama Aracı}

Çalışma kapsamında toplanan veriler, Burdur ili Bucak ilçesinde ilkokula giden öğrencileri olan velilerden, çalışma grubunu oluşturan okulların idarecileri ile görüşülerek veriler toplanmıștır. Yapılan çalışma ile ilgili yeterli bilgiler verilmiştir. Çalışmanın yapılabilmesi için gerekli izinler alınmıştır. Ölçek araştırmacı tarafindan ilkokul idarecilerine ve sınıf öğretmenlerine dağıtılmıştır. Okul idarecileri tarafindan ve öğretmenler aracılığıyla velilere ulaştırılmış, velilerden formları doldurmaları istenmiştir. Bu kapsamda 528 adet veliye ölçek yollanmıș, bu velilerden 418 adeti doldurarak okul idarecilerine veya sınıf öğretmenlerine teslim etmiştir. Bu araştırmada toplam 418 veliden elde edilen veriler kullanılmıştır.

Yapılan çalışmada Kılınç (2015) tarafından 'Okulöncesi Çağındaki Çocukların Teknoloji Kullanımı Hakkında Ebeveyn Görüşlerinin İncelenmesi' olarak gerçekleştirdiği yüksek lisans tez çalışmasında kullanılan 31 madde bu çalışmaya uyarlanarak "ilkokul çağı öğrencilerinin ders çalışma sürecinde teknolojik araç kullanımına ilişsin veli görüşleri” şeklinde kullanılmıştır.

Ölçek toplamda 25 maddeden oluşmaktadır. Likert tipine göre hazırlanmış olup soldan sağa "1Kesinlikle Katılmıyorum, 2- Katılmiyorum, 3-Fikrim Yok, 4-Kat1lıyorum, 5-Kesinlikle Kat1liyorum” şeklinde sıralanmıştır. Hazırlanan ilkokul çağı öğrencilerinin ders çalışma sürecinde teknolojik araç kullanımına ilişkin veli görüşleri ölçeği iki Türkçe öğretmeni, bir Bilişim ve Teknolojileri öğretmeni ve ölçme değerlendirme alanında öğretim üyesinin olduğu toplam dört kişilik uzman yardımıyla incelenmiştir. Ölçek toplamda 25 maddeden oluşup Likert Tipi şekline göre hazırlanmıştır.

Yapılan çalışmanın ön denemesi araştırmacının görev yaptığı Antalya ili Döşemealtı ilçesi Dağ ilkokulu birinci, ikinci, üçüncü, dördüncü sınıflarda öğrenim gören 127 öğrenci velisinin tamamına ulaşılarak yapılmıştır. Cronbach's Alpha Güvenirlik Katsayısı ,78 olarak hesaplanmıştır. Yapı geçerliği kavramsal yapının tam olarak açığa çıkarılması konusuyla ilgilidir. Yapı geçerliğini test etmek ve aynı niteliği ölçen değişkenleri bir araya getirerek ölçmeyi az sayıda faktör ile açıklamak amacıyla açımlayıcı faktör analizi yapılması gerekmektedir (Büyüköztürk, 2011; Şencan, 2005).

Açımlayıcı faktör analizi, araştırmacının ölçme aracının ölçtüğü faktörlerin sayısı hakkında bilgi sahibi olmadığı ve ölçme aracıyla ölçülen faktörlerin doğası hakkında bilgi edinmeye çalıştığı inceleme türüdür (Tavşancıl, 2010). Açımlayıcı faktör analizi birbiri ile ilişkili çok sayıda değişkeni bir araya getirerek kavramsal olarak anlamlı daha az sayıda yeni değişkenler bulmak amacıyla yapılır (Çokluk, Şekercioğlu ve Büyüköztürk, 2012).

Elde edilen verilerin faktör analizine uygunluğunu saptamak amaciyla Kaiser- Meyer Olkin (KMO) katsayısı ve Barlett's Sphericity testi yapılmıştır. KMO katsayısı, verilerin ve örneklem büyüklügünün seçilen analize uygun ve yeterli olduğunu belirlemek, Bartlett's Sphericity testi ise verilerin çok değişkenli normal dağılımdan gelip gelmediğini kontrol etmek amaciyla kullanılan istatistiksel bir tekniktir (Kan ve Akbaş, 2005). Açımlayıcı faktör analizinin yapılabilmesi için KMO değerinin en az .60 olması gerektiği uzmanlar tarafından ifade edilmiştir (Büyüköztürk, 2011). Pilot uygulamada elde edilen verilerin KMO değeri .76 olarak hesaplanmış ve verilerin faktör analizi yapabilmek için yeterli olduğu sonucuna ulaşılmıştır. Bartlett Sphericity testi ise $(\mathrm{x} 2=1576.931, \mathrm{p}=.000)$ anlaml bulunmuştur. Bartlett's testi değerinin .000 düzeyinde anlamlı bulunması, verilerin çok değişkenli normal dağılıma 
sahip olduğunu göstermektedir (Borg ve Gall, 1989; Tabachnick ve Fidell, 2013). Bu sonuçlara göre pilot çalışma sonrasında elde edilen verilerin faktör analizi yapmaya uygun olduğuna karar verilmiştir.

Yapıdaki faktör sayısına karar verilmesinin ardından maddelerin faktör yükleri ve binişik olma durumları incelenmiştir. Elde edilen faktör deseni ve maddelerin faktör yük değerleri Tablo 2'de verilmiştir. Yapılan analizler sonucunda ölçek 6 faktörlü ve 25 maddeli bir yapı sergilemektedir.

Tablo 2. İlkokul Çă̆g Öğrencilerinin Ders Çalışma Sürecinde Teknolojik Araç Kullanımına İlişkin Veli Görüşleri Ölçeğin Faktör Deseni

\begin{tabular}{|c|c|c|c|c|c|c|}
\hline $\begin{array}{l}\text { Madde } \\
\text { No. }\end{array}$ & 1. Faktör & 2. Faktör & 3. Faktör & 4. Faktör & 5. Faktör & 6. Faktör \\
\hline 21 & .718 & & & & & \\
\hline 22 & .704 & & & & & \\
\hline 23 & .835 & & & & & \\
\hline 17 & .788 & & & & & \\
\hline 24 & .516 & & & & & \\
\hline 4 & & .684 & & & & \\
\hline 5 & & .761 & & & & \\
\hline 7 & & .641 & & & & \\
\hline 25 & & .543 & & & & \\
\hline 8 & & .539 & & & & \\
\hline 14 & & .548 & & & & \\
\hline 11 & & & .734 & & & \\
\hline 19 & & & .789 & & & \\
\hline 9 & & & .756 & & & \\
\hline 15 & & & & .764 & & \\
\hline 20 & & & & .768 & & \\
\hline 3 & & & & .741 & & \\
\hline 16 & & & & .681 & & \\
\hline 10 & & & & & .787 & \\
\hline 13 & & & & & .765 & \\
\hline 12 & & & & & .597 & \\
\hline 1 & & & & & .701 & \\
\hline 6 & & & & & & .785 \\
\hline 2 & & & & & & .561 \\
\hline 18 & & & & & & .589 \\
\hline
\end{tabular}

Tablo 2'de görüldüğü üzere, ölçeğin boyutları düzeyinde faktör yük değerleri birinci faktör için .835 ile .516 arasında, ikinci faktör için .761 ile .539 arasında, üçüncü faktör için .789 ile .734 arasında, dördüncü faktör için .768 ile .681 arasında, beşinci faktör için .787 ile .597 arasında ve altıncı faktör için .785 ile .561 arasında değişmektedir. Analizler sonucunda elde edilen 6 faktör içerdikleri ifadelere göre isimlendirilmiştir. Buna göre birinci faktör "Teknolojik Araç Kullanımında Aile Rehberliği”, ikinci faktör "Teknolojik Araç Kullanmanın Faydaları", üçüncü faktör "Teknolojik Araç Kullanım Alanları", dördüncü faktör "Teknolojik Araç Kullanmanın Zararları", beşinci faktör "Teknolojik Araç Kullanım Becerisi” ve altıncı faktör "Öneriler" olarak isimlendirilmiştir.

İlkokul Çağı Öğrencilerinin Ders Çalışma Sürecinde Teknolojik Araç Kullanımına İlişkin Veli Görüşleri ölçeğin boyutlarının güvenirliğini hesaplamak için veriler üzerinde iç tutarlık analizi yapılmıştır. Yapılan analizler sonrasında her alt boyutu için Cronbach Alpha iç tutarlılık katsayıları Tablo 3'te gösterilmiştir. Buna göre birinci boyut için iç tutarl11ık katsayısı ,72 ikinci boyut için iç tutarlılık katsayısı ,84 üçüncü boyut için iç tutarlılık katsayısı, 76 dördüncü boyut için iç tutarlılık katsayısı, 87 beşinci boyut için iç tutarlılık katsayısı ,76 ve altıncı boyut için iç tutarlılık katsayısı ,78 olarak hesaplanmıştır. 
Tablo 3. İlkokul Çă̆ı Öğrencilerinin Ders Çalışma Sürecinde Teknolojik Araç Kullanımına İlişkin Veli Görüşleri Ölçeğin Güvenirlik Analizi

$\begin{array}{lc}\text { Faktörler } & \text { Cronbach Alpha }(\alpha) \text { Değeri } \\ \text { 1. Faktör } & 0,724396 \\ \text { 2. Faktör } & 0,843748 \\ \text { 3. Faktör } & 0,764983 \\ \text { 4. Faktör } & 0,867688 \\ \text { 5. Faktör } & 0,756611 \\ \text { 6. Faktör } & 0,786745 \\ \text { Toplam } & 0,780695\end{array}$

\section{Verilerin Analizi}

$\mathrm{Bu}$ çalışmada değişkenler arası farklılı̆̆ belirleyebilmek için parametric olmayan testlerden Mann Whitney U Testi analizi yapılmıştır. Ayrıca velilerin, öğrencilerin ders çalışma sürecinde TA kullanım düzeylerini ölçmek için toplanan veriler Sosyal Bilimler Veri Analizi Programı (SPSS) 22 paket programı ile analiz edilmiştir. Sonuçlarda gruplar arasında anlamlı farklılıkları bulmak için Kruskall Wallis Testi, Mann Whitney U Testi kullanılmıştır. Kruskall Wallis Testi bir faktör çatısı altında, iki ya da daha fazla bağımsız grubun ortalamalarını kıyaslamak için kullanılır. İlkokul çağı öğrencilerinin ders çalışma sürecinde TA (Teknolojik Araç; bilgisayar, telefon, tablet ve televizyon) kullanımlarında; veli cinsiyet değişkenine göre Mann-Whitney U Testi, yaş aralı̆g 1 değişkenine göre Kruskal-Wallis Testi, öğrenim düzeyi değişkenine Göre Kruskal-Wallis Testi, evde kullanılan TA sayısı değişkenine göre Kruskal-Wallis Testi, sınıf düzeyi değişkenine göre Kruskal-Wallis Testi, öğrencilerin TA kullanım süresi değiş̧enine göre Mann-Whitney U Testi ve internet bağlantı durumu değişkenine göre MannWhitney U Testi yapılmıştır.

\section{BULGULAR VE YORUM}

\section{Birinci Alt Probleme İlişkin Bulgular}

"İlkokul çağı öğrencilerinin ders çalışma sürecinde Teknolojik Araçların (TA) kullanımında veli görüşleri nasıldır?" alt probleme ilişkin bulgular ve yorumları Tablo 5'te verilmiştir.

Tablo 4. Veli Görüşlerinin Aritmetik Ortalama ve Standart Sapma Puanları

\begin{tabular}{lcc}
\hline \multicolumn{1}{c}{ Maddeler } & $\overline{\mathrm{x}}$ & $\mathrm{s}$ \\
\hline 1. Boyut: Teknolojik Araç Kullanımında Aile Rehberliği & & 1,03893 \\
\hline $\begin{array}{l}\text { İlkokula giden çocuğumu teknolojik araçlar yerine kardeşi ve arkadaşları ile birlikte oynamaya } \\
\text { teşvik ederim. }\end{array}$ & 4,2895 &, 94991 \\
\hline İlkokula giden çocuğuma teknolojik araçları kullandırırken süreyi sınırlandırırım. &, 99532 \\
\hline İlkokula giden çocuğumun kullanacağı bilgisayar programlarını dikkatlice seçerim. & 4,2615 & 1,06540 \\
\hline İlkokula giden çocuğum bilgisayar kullanırken yaptıkları ile ilgili ona sorular sorarım. & 4,2829 & 1,11944 \\
\hline $\begin{array}{l}\text { Teknolojik araçlardaki oyun seçimlerinde ya da oyunun oynanmasında çocuğum tamamen } \\
\text { özgürdür. }\end{array}$ & 1,9046 & \\
\hline 2. Boyut: Teknolojik Araç Kullanmanın Faydaları & & \\
\hline
\end{tabular}


Uygun programlar kullanıldığında bilgisayar, tablet gibi teknolojik araçlar çocukların dilsel

Eğitici programlar kullanıldığında bilgisayarlar, tabletler gibi teknolojik araçlar ilkokul $\quad 2,6927$

Teknolojik araçların kullanımı çocuğumun dikkat gelişimini arttırır.

2,3932

1,06287

Teknolojik araç kullanmalarına izin verilen çocuklar daha yaratıcıdır.

İlkokula giden çocuğum günlük yaşamında ve eğitimi sırasında öğrendiği pek çok kavramı

\begin{tabular}{lcc}
\hline $\begin{array}{l}\text { İlkokula giden çocuğumun öğrenmelerinin kalıcı olması için bilgisayarı, tableti vb. teknolojik } \\
\text { araçları kullanım. }\end{array}$ & 2,7946 & 1,11446 \\
\hline Çocuğuma şekilleri öğretmek için bilgisayar, tablet vb. gibi teknolojik araçları kullanırım. & 2,7664 & 1,15355 \\
\hline Çocuğumun araştırmalarında bilgisayar, tablet gibi teknolojik araçları kullanırım. & 3,6790 & 1,05571 \\
\hline
\end{tabular}

4. Boyut: Teknolojik Araç Kullanmanın Zararları

\begin{tabular}{|c|c|c|}
\hline $\begin{array}{l}\text { İlkokul çağındaki çocukların teknolojik araçları sık kullanmaları onların arkadaşları ile olan } \\
\text { iliş̧kilerini zayıflatır. }\end{array}$ & 4,0882 & 1,21095 \\
\hline $\begin{array}{l}\text { Çocukların bilgisayarla fazlaca zaman geçirmesi çocukların beden sağlığının bozulmasına } \\
\text { neden olur. }\end{array}$ & 4,1796 & 1,22296 \\
\hline Teknolojik araçların kullanımı çocukların sosyalleşmesini olumsuz yönde etkiler. & 4,0898 & 1,14590 \\
\hline Teknolojik araçları fazlaca kullanan çocuklar kendilerini rahatlıkla ifade edemezler. & 3,7840 & 1,17535 \\
\hline \multicolumn{3}{|l|}{ 5. Boyut: Teknolojik Araç Kullanım Becerisi } \\
\hline İlkokula giden çocuğum ders çalışma sürecinde akıllı telefonları rahatlıkla kullanabilir. & 2,3456 & 1,26595 \\
\hline İlkokula giden çocuğum internet üzerinden ders araştırmaları yapmayı becerir. & 3,3407 & 1,16210 \\
\hline İlkokula giden çocuğumun telefonumdan ders araştırmaları yapmasına izin veririm. & 3,3447 & 1,14948 \\
\hline İlkokula giden çocuğum teknolojik araçları kullanırken zorlanır. & 2,4866 & 1,16755 \\
\hline \multicolumn{3}{|l|}{ 6. Boyut: Öneriler } \\
\hline $\begin{array}{l}\text { Rehber eşliğinde kullanıldığında teknolojik araçlar ilkokul çağındaki çocukların ders } \\
\text { çalışmalarında oldukça faydalıdır. }\end{array}$ & 3,8034 & 1,10855 \\
\hline $\begin{array}{l}\text { İlkokul çağındaki çocukların ders çalışmalarında bilgisayar, tablet gibi teknolojik araçlar } \\
\text { kullanılmalıdır. }\end{array}$ & 3,1214 & 1,14404 \\
\hline İlkokul çağındaki çocuklar kesinlikle bilgisayar, tablet gibi teknolojik araçlar kullanmalıdır. & 2,7560 & 1,15228 \\
\hline
\end{tabular}


Araştırmada Tablo 4 incelendiğinde en yüksek maddelerin ortalamaları: Teknolojik Araç Kullanımında Aile Rehberliği alt boyutunda "ilkokula giden öğrencileri TA yerine kardeşi ve arkadaşları ile birlikte oynamaya teşvik ederim $(\bar{X}=4,29)$, ilkokula giden öğrencilere TA kullandırırken süreyi sınırlandırırım $(\bar{X}=4,26)$, ilkokula giden öğrencileri kullanacağı bilgisayar programlarını dikkatlice seçerim $(\bar{X}=$ $4,28)$, ilkokula giden öğrencilere bilgisayar kullanırken yaptıkları ile ilgili ona sorular sorarım $(\bar{X}=$ 4,08). En düşük maddenin ortalaması ise, "TA oyun tercihlerinde ya da oyunun oynanmasında ilkokul öğrencileri tamamen özgürdür $(\bar{X}=1,90)$ ”. Velilerin, ilkokul ögrencilerini TA kullanırken tamamen özgür bırakmama nedeni olarak öğrencilerin henüz TA kullanımında karşılaşabilecekleri tehlikelere karşı kendilerini koruyamayacakları düşüncesi olabilir. Araştırma sonuçları göz önüne alınırsa velilerin ilkokula giden öğrenciler üzerinde aile rehberliğine önem verdiği görülmektedir.

En yüksek maddelerin ortalamaları: Teknolojik Araç Kullanmanın Faydaları alt boyutunda, "uygun programlar kullanıldığında TV, bilgisayar, tablet gibi TA'lar öğrencilerin dilsel gelişimine katkı sağlar $(\bar{X}=3,20)$, eğitici programlar kullanıldığında bilgisayar, tablet gibi TA'lar ilkokul eğitiminde kitaplara göre daha faydalıdır $(\overline{\mathrm{X}}=2,69)$, TA'ları kullanmalarına izin verilen öğrenciler daha yaratıcıdır $(\overline{\mathrm{X}}=2,58)$, ilkokula giden öğrencilerin günlük yaşamında ve eğitimi sırasında öğrendiği pek çok kavramı TA'ların sunduğu oyunlar ile pekiştirir $(\overline{\mathrm{X}}=2,58)$. En düşük maddelerin ortalaması ise, "TA'ların sıklıkla kullanımı öğrencilerin dünyayı daha iyi tanımalarını sağlar $(\overline{\mathrm{X}}=2,47)$, TA'ların kullanımı öğrencilerin dikkat gelişimini arttırır $(\overline{\mathrm{X}}=2,39)$ ). Velilerin, ilkokul ögrencilerinin TA kullanırken; hayatı daha iyi tanımaları ile fazla ilgisi olmadığını düşündükleri bunun nedeninin ise hayatın sosyal ilişkiler ile canlı olarak öğrenilebileceğini savunmaları olabilir. TA kullanımlarının öğrencileri tek bir noktaya sürekli bakmaları ile gerçekleştiğini düşünmeleri böylece öğrencilerin dikkat gelişimini artırmadıklarını savundukları söylenebilir.

En yüksek maddelerin ortalamaları: Teknolojik Araç Kullanım Alanları alt boyutuna bakıldığında, "ilkokul öğrencilerinin araştırmalarında bilgisayar, tablet gibi TA'ları kullanırım $(\bar{X}=3,68)$, ilkokula giden öğrencilerin öğrenmelerinin kalıcı olması için bilgisayarı, tableti vb. TA'ları kullanırım ( $\overline{\mathrm{X}}=2,80)$ ". En düşük maddenin ortalaması ise, "ilkokul öğrencilerine şekilleri öğretmek için TV, bilgisayar, tablet vb. gibi TA'ları kullanırım ( $\bar{X}=2,77)$ ". Velilerin, ilkokul öğrencileri TA kullanırken ihtiyaç duydukları araştırma alanları ve öğrenme etkinliklerini TA kullanmadan da yürütülebilineceğini savundukları söylenebilir.

En yüksek maddelerin ortalamaları: Teknolojik Araç Kullanmanın Zararları alt boyutuna bakıldığında, "ilkokul öğrencilerinin bilgisayarla fazlaca zaman geçirmesi öğrencilerin beden sağlığının bozulmasına neden olur $(\overline{\mathrm{X}}=4,18)$, ilkokul çağındaki öğrencilerin TA'ları sürekli kullanmaları arkadaşlık ilişkilerini zayıflatır $(\overline{\mathrm{X}}=4,09)$, TA'ların kullanımı ilkokul öğrencilerin sosyalleşmesini olumsuz yönde etkiler $(\overline{\mathrm{X}}=$ 4,09), TA'ları fazlaca kullanan ilkokul öğrencileri kendilerini rahatlıkla ifade edemezler $(\bar{X}=3,78)$ ”. Velilerin ilkokul öğrencileri TA kullanırken; gerçek arkadaşlıklar yerine sanal arkadaşlıkları tercih etmeleri, kendi düşüncelerine karşı bir düşüncenin hiçbir zaman olmadığı ve olumsuz davranış ve söylemlerine karşı bir tepkinin verilmediği için arkadaşlık ilişkilerini zayıflattığı, sosyalleşmelerinin olumsuz etkilendiği ve kendilerini ifade eden kelime ve cümle sayılarındaki azalış ile söyleyeceklerini rahatıkla anlatamadıkları düşüncesi hâkim olabilir. İlkokul öğrencilerinin erken yaştan itibaren TA'ların başında uzun süre durmaları sonucunda duruş bozukluklarına neden olabileceği düşüncesi hâkim olabilir. İlkokula giden öğrencilerin TA'lar karşısında fazla zaman geçirmeleri onları sosyal, fiziksel ve bilişsel olarak olumsuz etkilediği görülür.

En yüksek maddelerin ortalamaları: Teknolojik Araç Kullanım Becerisi alt boyutuna bakıldığında, "İlkokula giden öğrenciler internet üzerinden ders araştırmaları yapmayı becerir $(\overline{\mathrm{X}}=3,34)$, ilkokula giden öğrencinin telefonumdan ders araştırmaları yapmasına izin veririm $(\overline{\mathrm{X}}=3,34)$.” En düşük maddelerin ortalaması ise, "ilkokula giden öğrenciler TA'lar kullanırken zorlanır $(\overline{\mathrm{X}}=2,49)$, ilkokula giden öğrenciler ders çalışma sürecinde akıllı telefonları rahatlıkla kullanabilir $(\bar{X}=2,35)$.” Velilerin ilkokula giden öğrencileri TA'ları ders araştırma süreçlerinde aslında rahatlıkla kullanamadıklarını nedeninin ise daha çok oyun oynama becerilerine sahip olduklarını savundukları söylenebilir.

En yüksek maddelerin ortalamaları: Öneriler alt boyutuna bakıldığında, "rehber eşliğinde kullanıldığında TA'lar ilkokul çağındaki öğrencilerin ders çalışmalarında oldukça faydalıdır ( $\overline{\mathrm{X}}=3,80)$, ilkokul çağındaki öğrencilerin ders çalışmalarında bilgisayar, tablet gibi TA'lar kullanılmalıdır $(\overline{\mathrm{X}}=$ 
3,12)”. En düşük maddenin ortalaması ise, "İlkokul çağındaki öğrenciler kesinlikle bilgisayar, tablet gibi TA'ları kullanmalıdır ( $\overline{\mathrm{X}}=2,76)$.” Velilerin ilkokul öğrencileri TA kullanırken; TA'ların ders çalışma süreçlerinde kullanımını zorunluluk olarak görmediğini, TA başında yapabileceği etkinlikleri yaparak yaşayarak yapılması ile sonuca ulaşılabileceği düşüncesi hâkim olabilir.

\section{İkinci Alt Probleme İlişkin Bulgular}

"İlkokul çağı öğrencilerinin ders çalışma sürecinde Teknolojik Araç (TA) kullanımında veli görüşleri cinsiyete göre anlamlı bir fark göstermekte midir?" alt probleme ilişkin bulgular ve yorumları Tablo 5 'te verilmiştir.

Tablo 5. Veli Görüşlerinin Cinsiyet Değişkenine Göre Mann-Whitney U Testi Sonuçları

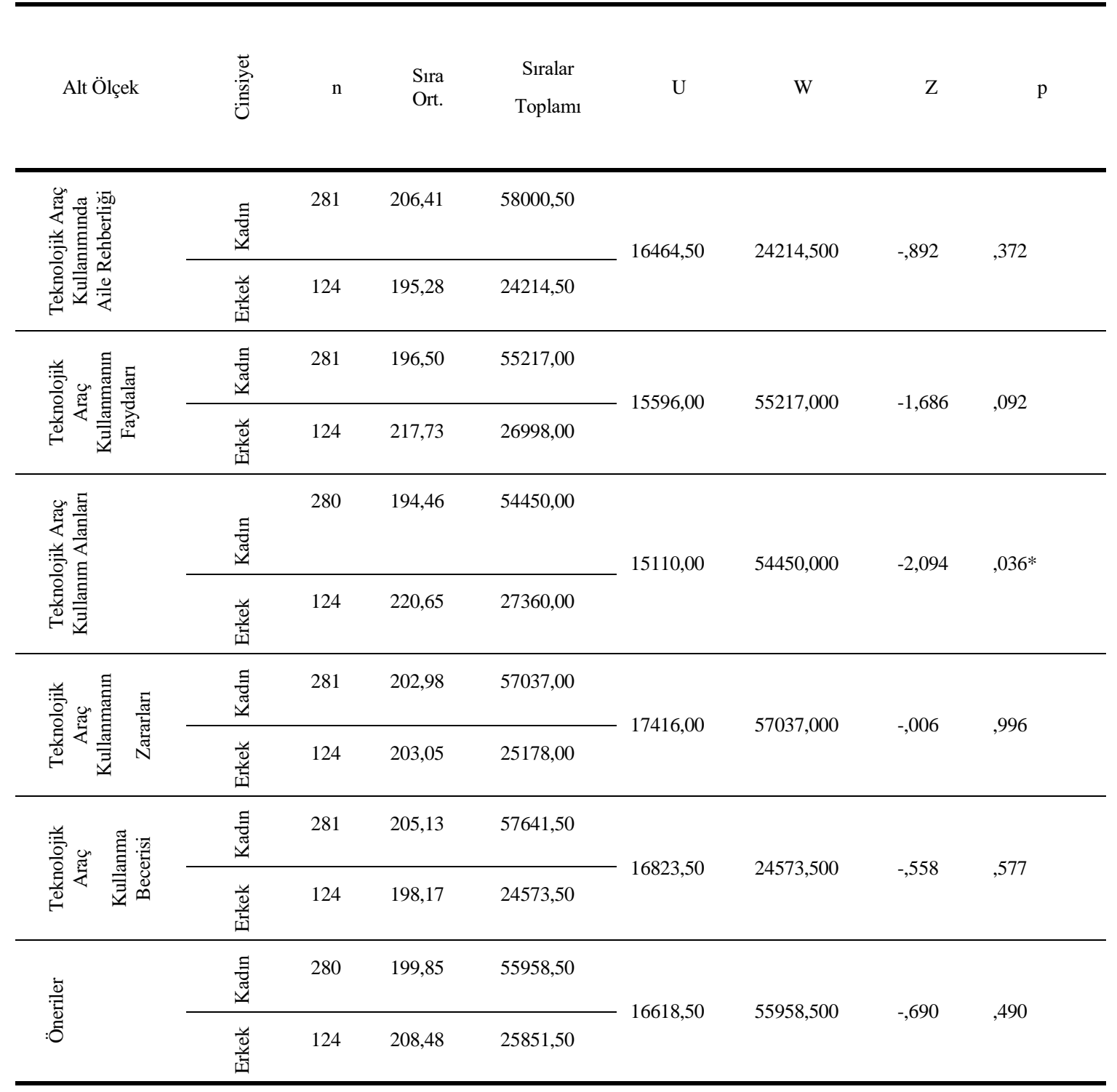

Anlamll1ık düzeyi $=* \mathrm{p}<, 05$

Tablo 5'te Mann Whitney U Testi analiz sonuçlarına göre, yalnızca teknolojik araç kullanım alanları alt boyutunda erkek veliler lehine anlamlı bir farkl11ı vardır [U=15110,000; $Z=-2,094 ; \mathrm{p}<, 05] . \mathrm{Bu}$ sonuçlara göre erkek velilerin (Sıra ortalaması: 220,65) kadın velilere (Sıra ortalamas1: 194,46) oranla ilkokul çağı öğrencilerinin ders çalışma sürecinde TA'ları kullanımlarının daha fazla olduğu belirlenmiştir. Farklılığın ise öğrenciler ile boş zamanlarını daha çok öğrencilerle kullanan kadın velilerin TA kullanımına daha endişeli yaklaşmaları olduğu söylenebilir. Erkek veliler kadın velilere göre TA'ları ilkokul eğitiminde çeşitli kullanım alanlarının olduğunu savunmaktadır. Bunun nedeni 
olarak erkek velilerin TA eğitim düzeylerinin kadın velilere göre daha yüksek olduğu düşünülebilir. Erkek velilerin TA kullanımına başlamaları kadın velilere göre daha erken yaşta olduğundan erkek veliler, öğrencilerin TA kullanımlarının desteklenmesi gerektiğini düşündüğü söylenebilir.

Diğer beş boyutun analiz sonuçları incelendiğinde ise velilerin cinsiyet değişkeni açısından teknolojik araç kullanımında aile rehberliği $[\mathrm{U}=16464,500 ; \mathrm{Z}=-, 892 ; \mathrm{p}>$,05], teknolojik araç kullanmanın faydaları $[U=15596,000 ; Z=-1,686 ; p>, 05]$, teknolojik araç kullanmanın zararları $[U=17416,000 ; Z=-$ ,006; $\mathrm{p}>$,05], teknolojik araç kullanım becerisi [U=16823,500; $\mathrm{Z}=-, 558 ; \mathrm{p}>, 05]$ ve öneriler [U= 16618,500; Z= -,690; p> ,05] alt boyutlarında velilerin düşünceleri arasında herhangi bir anlamlı fark bulunamamıştır.

\section{Üçüncü Alt Probleme İlişkin Bulgular}

"İlkokul çağı öğrencilerinin ders çalışma sürecinde Teknolojik Araç (TA) kullanımında veli görüşleri yaş aralığına göre anlamlı bir fark göstermekte midir?" alt probleme ilişkin bulgular ve yorumları Tablo 6'da verilmiştir.

Tablo 6. Veli Görüşlerinin Yaş Aralı̆̆ı Değişkenine Göre Kruskal-Wallis Testi Sonuçları

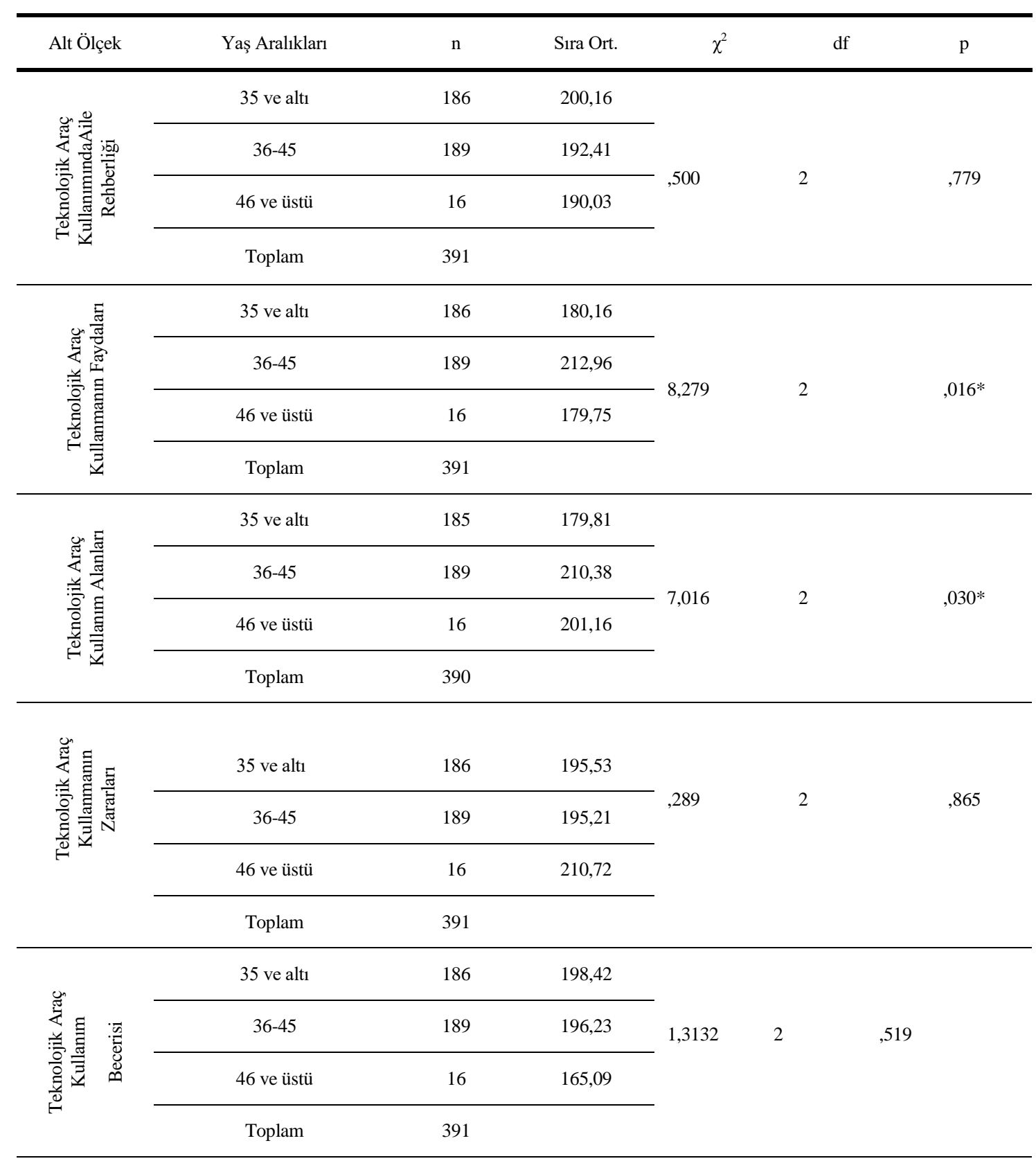




\begin{tabular}{|c|c|c|c|c|c|c|}
\hline \multirow{4}{*}{ 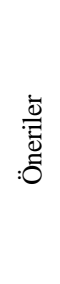 } & 35 ve altı & 185 & 190,45 & \multirow{4}{*}{\multicolumn{2}{|c|}{ 926 }} & \multirow{4}{*}{,629 } \\
\hline & $36-45$ & 189 & 201,10 & & & \\
\hline & 46 ve üstü & 16 & 187,81 & & & \\
\hline & Toplam & 391 & & & & \\
\hline
\end{tabular}

Tablo 6'da Kruskal-Wallis Testi sonuçlarına göre, alt boyutların teknolojik araç kullanmanın faydaları alt boyutunda $\left[\chi^{2}(2)=8,279, \mathrm{p}<, 05\right]$ ve teknolojik araç kullanım alanları $\left[\chi^{2}(2)=7,016, \mathrm{p}<, 05\right]$ alt boyutunda anlamlı bir farklılık olduğu belirlenmiştir. Analizlerin sonucunda farklılığın TA kullanmanın faydaları alt boyutunda 36-45 yaş velileri lehine olduğu tespit edilmiştir. Bu farklılığın nedeni olarak TA'ları gerekli olduğu durumlarda kullanan kesimin yaş aralığından kaynaklı olduğunu söylenebilir. Teknolojik araç kullanım alanları alt boyutunda ki farklılı̆̆ı 36-45 yaş velileri lehine olduğu tespit edilmiştir. Bu farklılığın nedeni ise bu yaş grubu velilerin artık TA'ların hayatın hangi alanlarında kullanılabileceğini, öğrencilere hangi alanlarda fayda getirebileceğini biliyor olmasından kaynaklı olduğu söylenebilir. 36-45 yaş velilerinin öğrenciler ile daha güçlü bir iletişime sahip olması sonucundan kaynaklı teknolojik araç kullanmanın faydaları ve teknolojik araç kullanım alanlarında onların lehine anlamlı farkın bulunduğu söylenebilir.

Diğer dört boyutun analiz sonuçları incelendiğinde ise velilerin yaş aralıkları değişkeni açısından teknolojik araç kullanımında aile rehberliği $\left[\chi^{2}(2)=, 500, \mathrm{p}>, 05\right]$, teknolojik araç kullanmanın zararları $\left[\chi^{2}(2)=, 289, \mathrm{p}>, 05\right]$, teknolojik araç kullanım becerisi $\left[\chi^{2}(2)=1,313, \mathrm{p}>, 05\right]$ ve öneriler $\left[\chi^{2}(2)=, 926, \mathrm{p}>\right.$ ,05] alt boyutlarında velilerin düşünceleri arasında herhangi bir anlamlı fark bulunamamıştır.

\section{Dördüncü Alt Probleme İlişskin Bulgular}

“İlkokul çağı öğrencilerinin ders çalışma sürecinde Teknolojik Araç (TA) kullanımında veli görüşleri ögrenim düzeyine göre anlamlı bir fark göstermekte midir?" alt probleme ilişkin bulgular ve yorumları Tablo 7'de verilmiştir.

Tablo 7. Veli Görüşlerinin Öğrenim Düzeyi Değiş̧kenine Göre Kruskal-Wallis Testi Sonuçları

\begin{tabular}{|c|c|c|c|c|c|c|}
\hline Alt Ölçek & Öğrenim Durumları & $\mathrm{n}$ & Sira Ort. & $\chi^{2}$ & df & $\mathrm{p}$ \\
\hline \multirow{6}{*}{ 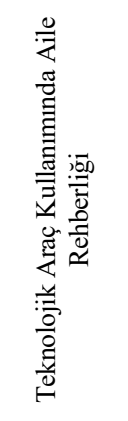 } & İlkokul & 108 & 192,34 & \multirow{6}{*}{11,420} & \multirow{6}{*}{4} & \multirow{6}{*}{, $022^{*}$} \\
\hline & Ortaokul & 67 & 173,80 & & & \\
\hline & Lise & 124 & 213,82 & & & \\
\hline & Üniversite & 95 & 230,79 & & & \\
\hline & Lisansüstü & 15 & 199,23 & & & \\
\hline & Toplam & 409 & & & & \\
\hline \multirow{6}{*}{ 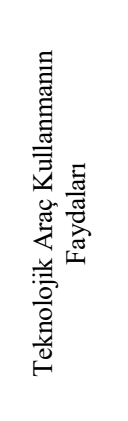 } & İlkokul & 108 & 222,19 & \multirow{6}{*}{8,899} & \multirow{6}{*}{4} & \multirow{6}{*}{, 064} \\
\hline & Ortaokul & 67 & 211,72 & & & \\
\hline & Lise & 124 & 201,16 & & & \\
\hline & Üniversite & 95 & 197,37 & & & \\
\hline & Lisansüstü & 15 & 131,30 & & & \\
\hline & Toplam & 409 & & & & \\
\hline
\end{tabular}




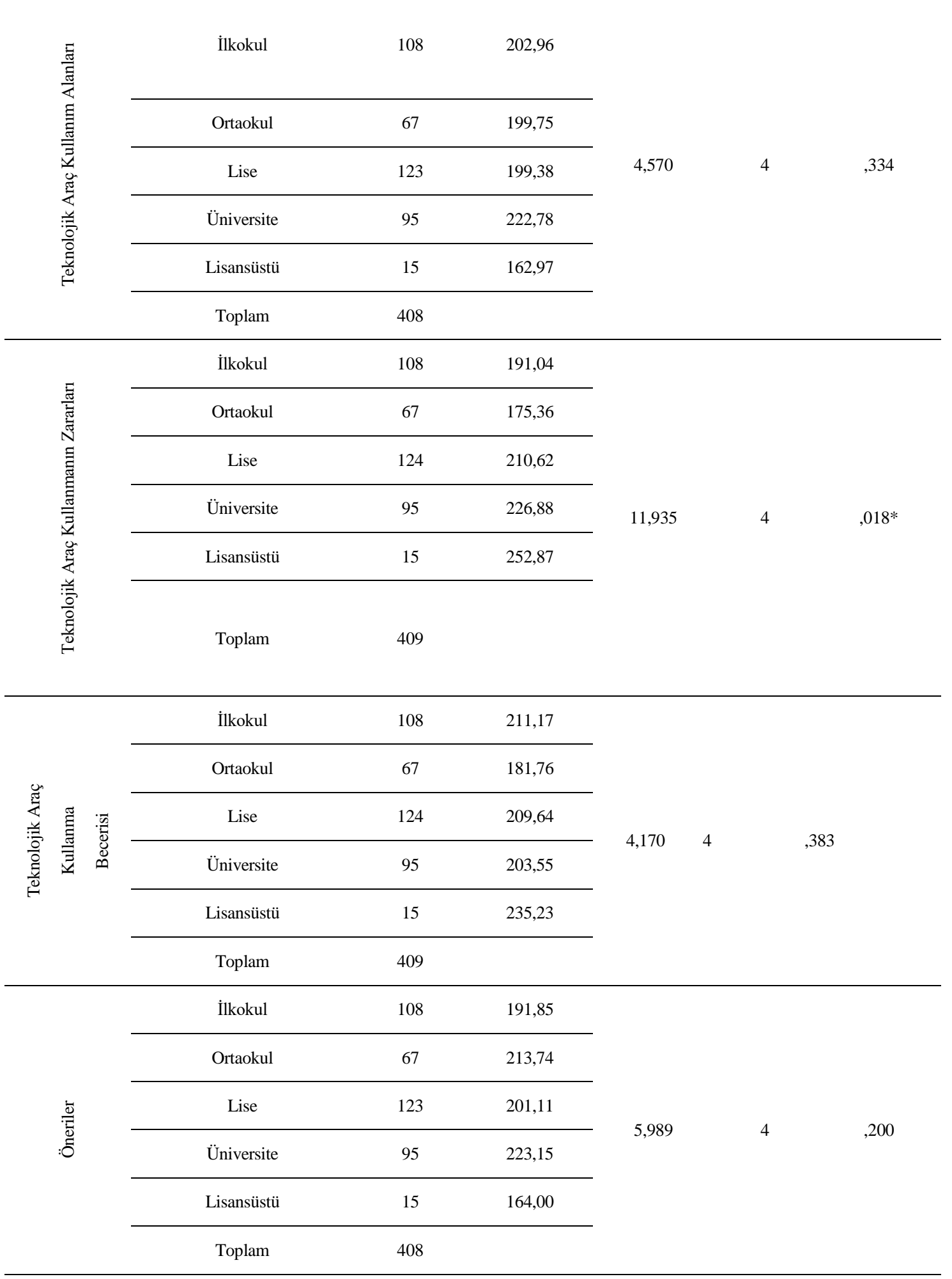

Anlamlılık düzeyi $=* \mathrm{p}<, 05$

Tablo 7'de Kruskal-Wallis Testi sonuçlarına göre, alt boyutların teknolojik araç kullanımında aile rehberliği $\left[\chi^{2}(2)=11,420, p<, 05\right]$ ve teknolojik araç kullanmanın zararları $\left[\chi^{2}(2)=11,935, p<, 05\right]$ alt boyutlarında anlamlı bir farkl1lı olduğu görülmüștür. Analizlerin sonucunda farklılığın ise öğrenim düzeyi arttıkça aile rehberliğine verilen önemin arttığı ve teknolojik araç kullanmanın zararlı etkilerinin daha fazla olduğu görüşünü düşündükleri görülmüştür. Çünkü velilerin öğrenim düzeyi arttıkça TA'ların 
çağın getirdiği yeniliklere bağımlılık derecesine neden olduğu ve öğrencilerin daha çok zararlı sonuçlarına maruz kaldıkları düşüncesini benimsedikleri söylenebilir.

Diğer dört boyutun analiz sonuçları incelendiğinde ise öğrenim düzeyi değiş̧keni açısından teknolojik araç kullanmanın faydaları $\left[\chi^{2}(2)=8,899, p>, 05\right]$, teknolojik araç kullanım alanları $\left[\chi^{2}(2)=4,570, p>\right.$ ,05], teknolojik araçları kullanım becerisi $\left[\chi^{2}(2)=4,170, p>, 05\right]$ ve öneriler $\left[\chi^{2}(2)=5,989, p>, 05\right]$ alt boyutlarında velilerin düşünceleri arasında herhangi bir anlamlı fark bulunamamıştır.

\section{Beşinci Alt Probleme İlişskin Bulgular}

"İlkokul çağı öğrencilerinin ders çalışma sürecinde Teknolojik Araç (TA) kullanımında veli görüşleri evde kullanılan TA sayısına göre anlamlı bir fark göstermekte midir?" alt probleme ilişkin bulgular ve yorumları Tablo 8'de verilmiştir.

Tablo 8. Veli Görüşlerinin Evde Kullanılan TA Sayısı Değisskenine Göre Kruskal-Wallis Testi Sonuçları

\begin{tabular}{|c|c|c|c|c|c|c|}
\hline Alt Ölçek & Sinıfi & $\mathrm{n}$ & Sira Ort. & $\chi^{2}$ & $\mathrm{df}$ & $\mathrm{P}$ \\
\hline \multirow{5}{*}{ 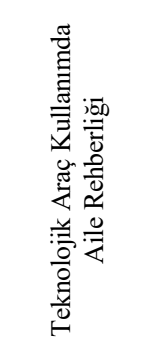 } & 1 adet & 102 & 191,35 & \multirow{5}{*}{3,652} & \multirow{5}{*}{3} & \multirow{5}{*}{,302 } \\
\hline & 2 adet & 152 & 197,24 & & & \\
\hline & 3 adet & 121 & 218,38 & & & \\
\hline & 4 adet & 30 & 209,73 & & & \\
\hline & Toplam & 405 & & & & \\
\hline \multirow{5}{*}{ 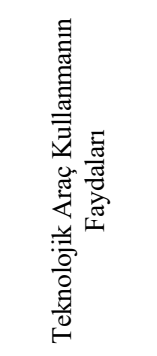 } & 1 adet & 102 & 192,37 & \multirow{5}{*}{3,728} & \multirow{5}{*}{3} & \multirow{5}{*}{,292 } \\
\hline & 2 adet & 152 & 198,89 & & & \\
\hline & 3 adet & 121 & 219,66 & & & \\
\hline & 4 adet & 30 & 192,73 & & & \\
\hline & Toplam & 405 & & & & \\
\hline \multirow{5}{*}{ 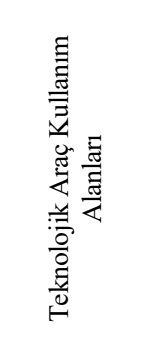 } & 1 adet & 102 & 176,20 & \multirow{5}{*}{7,314} & \multirow{5}{*}{3} & \multirow{5}{*}{,063 } \\
\hline & 2 adet & 151 & 214,89 & & & \\
\hline & 3 adet & 121 & 207,41 & & & \\
\hline & 4 adet & 30 & 209,77 & & & \\
\hline & Toplam & 404 & & & & \\
\hline \multirow{5}{*}{ 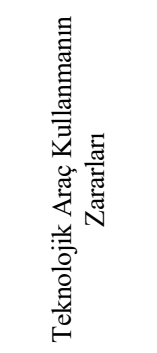 } & 1 adet & 102 & 191,75 & \multirow{5}{*}{1,918} & \multirow{5}{*}{3} & \multirow{5}{*}{,590 } \\
\hline & 2 adet & 152 & 208,58 & & & \\
\hline & 3 adet & 121 & 201,46 & & & \\
\hline & 4 adet & 30 & 219,18 & & & \\
\hline & Toplam & 405 & & & & \\
\hline \multirow{2}{*}{ 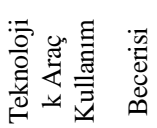 } & 1 adet & 102 & 199,66 & \multirow[t]{2}{*}{ 4,78933 } & \multirow[t]{2}{*}{3} & \multirow[t]{2}{*}{ 188 } \\
\hline & 2 adet & 152 & 192,39 & & & \\
\hline
\end{tabular}




\begin{tabular}{|c|c|c|c|c|c|c|}
\hline & 3 adet & 121 & 210,12 & & & \\
\hline & 4 adet & 30 & 239,37 & & & \\
\hline & Toplam & 405 & & & & \\
\hline \multirow{5}{*}{ 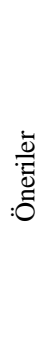 } & 1 adet & 102 & 166,04 & \multirow{5}{*}{15,829} & \multirow{5}{*}{3} & \multirow{5}{*}{, $001^{*}$} \\
\hline & 2 adet & 151 & 218,85 & & & \\
\hline & 3 adet & 121 & 204,20 & & & \\
\hline & 4 adet & 30 & 237,32 & & & \\
\hline & Toplam & 404 & & & & \\
\hline
\end{tabular}

Anlaml11ık düzeyi $={ }^{*} \mathrm{p}<, 05$

Tablo 8'de Kruskal-Wallis Testi sonuçlarına göre, alt boyutların sadece öneriler $\left[\chi^{2}(2)=15,829, p<, 05\right]$ alt boyutunda anlamlı bir farklılık olduğu görülmüştür. Analizlerin sonucunda farklılı̆̆ın ise TA sayısı arttıkça velilerin daha fazla TA kullanımına yönelik önerilerinin arttığı görülmüştür. Velilerin öğrencilerin TA'lar ile etkileşim seviyelerinin durumu arttıkça velilerde oluşan endişe durumlarının artmasından kaynaklı nasıl daha faydalı kullanılabilir sorusuna cevap aradıkları söylenebilir.

Diğer beş boyutun analiz sonuçları incelendiğinde ise TA sayısı değişkeni açısından teknolojik araç kullanımında aile rehberliği $\left[\chi^{2}(2)=3,652, p>, 05\right]$, teknolojik araç kullanmanın faydaları $\left[\chi^{2}(2)=3,728\right.$, $\mathrm{p}>, 05]$,teknolojik araç kullanım alanları $\left[\chi^{2}(2)=7,314, \mathrm{p}>, 05\right]$, teknolojik araç kullanmanın zararları $\left[\chi^{2}(2)=1,918, p>, 05\right]$ ve teknolojik araç kullanım becerisi $\left[\chi^{2}(2)=4,789, p>, 05\right]$ alt boyutlarında velilerin düşünceleri arasında herhangi bir anlamlı fark bulunamamıştır.

\section{Altıncı Alt Probleme İlişkin Bulgular}

“İlkokul çağı öğrencilerinin ders çalışma sürecinde Teknolojik Araç (TA) kullanımında veli görüşleri öğrencilerin sınıf düzeylerine göre anlamlı bir fark göstermekte midir?” alt probleme ilişkin bulgular ve yorumları Tablo 9'da verilmiştir.

Tablo 9. Veli Görüşlerinin Öğrencilerin Sinlf Düzeyi Değişkenine Göre Kruskal-Wallis Testi Sonuçları

\begin{tabular}{|c|c|c|c|c|c|c|}
\hline Alt Ölçek & Sinifi & $\mathrm{n}$ & Sira Ort. & $\chi^{2}$ & df & $\mathrm{p}$ \\
\hline \multirow{5}{*}{ 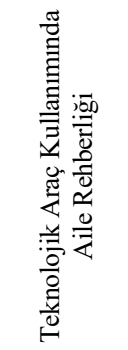 } & 1.sinif & 73 & 194,60 & \multirow{5}{*}{1,715} & \multirow{5}{*}{3} & \multirow{5}{*}{,63 } \\
\hline & 2.sinif & 113 & 191,91 & & & \\
\hline & 3.sinif & 85 & 188,93 & & & \\
\hline & 4.sinif & 121 & 207,25 & & & \\
\hline & Toplam & 392 & & & & \\
\hline \multirow{5}{*}{ 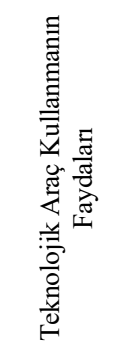 } & 1.sinif & 73 & 182,58 & \multirow{5}{*}{6,894} & \multirow{5}{*}{3} & \multirow{5}{*}{,075 } \\
\hline & $2 . \sin 1 f$ & 113 & 188,07 & & & \\
\hline & 3.sinif & 85 & 188,02 & & & \\
\hline & 4.sinif & 121 & 218,73 & & & \\
\hline & Toplam & 392 & & & & \\
\hline
\end{tabular}




\begin{tabular}{|c|c|c|c|c|c|c|}
\hline \multirow{5}{*}{ 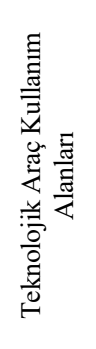 } & 1.sinif & 73 & 175,18 & \multirow{5}{*}{4,670} & \multirow{5}{*}{3} & \multirow{5}{*}{ 198 } \\
\hline & $2 . \sin 1 f$ & 113 & 197,79 & & & \\
\hline & 3.sinif & 84 & 191,08 & & & \\
\hline & 4.sinif & 121 & 210,30 & & & \\
\hline & Toplam & 392 & & & & \\
\hline \multirow{5}{*}{ 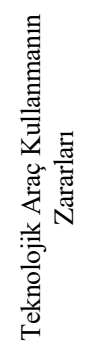 } & 1.sinif & 73 & 202,67 & \multirow{5}{*}{1,378} & \multirow{5}{*}{3} & \multirow{5}{*}{ 711 } \\
\hline & 2.sinif & 113 & 189,71 & & & \\
\hline & 3.sinıf & 85 & 205,87 & & & \\
\hline & 4.sinif & 121 & 192,53 & & & \\
\hline & Toplam & 392 & & & & \\
\hline \multirow{5}{*}{ 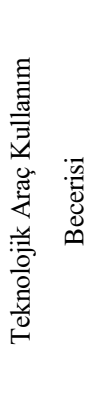 } & 1.sinif & 73 & 166,08 & \multirow{5}{*}{14,5443} & \multirow{5}{*}{3} & \multirow{5}{*}{, $002 *$} \\
\hline & 2.sinif & 113 & 180,96 & & & \\
\hline & 3.sinif & 85 & 207,28 & & & \\
\hline & 4.sinıf & 121 & 221,79 & & & \\
\hline & Toplam & 392 & & & & \\
\hline \multirow{5}{*}{ 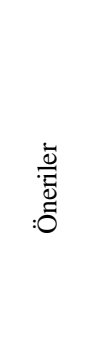 } & 1.sinif & 73 & 164,39 & \multirow{5}{*}{11,937} & \multirow{5}{*}{3} & \multirow{5}{*}{,008* } \\
\hline & 2.sinif & 113 & 188,30 & & & \\
\hline & 3.sinif & 84 & 199,28 & & & \\
\hline & 4.sinif & 121 & 219,99 & & & \\
\hline & Toplam & 392 & & & & \\
\hline
\end{tabular}

Tablo 9'da Kruskal-Wallis Testi sonuçlarına göre, alt boyutların teknolojik araç kullanım becerisi alt boyutunda $\left[\chi^{2}(2)=14,544, p<, 05\right]$ ve öneriler alt boyutunda $\left[\chi^{2}(2)=11,937, p<, 05\right]$ anlamlı bir farkl111k olduğu belirlenmiştir. Analizlerin sonucunda farklılığın, ilkokul çağı öğrencilerinin ders çalışma sürecinde teknolojik araç kullanım becerisi alt boyutunda ilkokul sınıf düzeylerinde üçüncü sınıflar ve dördüncü sınıflar lehine olduğu tespit edilmiştir. $\mathrm{Bu}$ farklılığın nedeni olarak fiziksel ve zihinsel gelişimin giderek artması sonucunda öğrencilerin teknolojik araç kullanım becerilerine yansımasından kaynaklı olduğu söylenebilir. Öneriler alt boyutunda ki farklılığın da ilkokulda ilerleyen sınıf seviyeleri lehine doğru olduğu tespit edilmiştir. Bu farklılığın nedeni ise ilkokulda ilerleyen sınıflarda öğrencilerin araştırma gereksinimlerinin ve ders konularının artması ile birlikte veli başarı beklentilerinin oluşması olduğu söylenebilir.

Diğer dört boyutun analiz sonuçları incelendiğinde ise sınıf düzeyleri değişkeni açısından teknolojik araç kullanımında aile rehberliği $\left[\chi^{2}(2)=1,715, p>, 05\right]$, teknolojik araç kullanmanın faydaları $\left[\chi^{2}(2)=6,894\right.$, $\mathrm{p}>, 05]$, teknolojik araç kullanım alanları $\left[\chi^{2}(2)=4,670, \mathrm{p}>, 05\right]$ ve teknolojik araç kullanmanın zararları $\left[\chi^{2}(2)=1,378, p>, 05\right]$ alt boyutlarında velilerin düşünceleri arasında herhangi anlamlı fark bulunamamıştır. 


\section{Yedinci Alt Probleme İlişkin Bulgular}

"İlkokul çağı öğrencilerinin ders çalışma sürecinde Teknolojik Araç (TA) kullanımında veli görüşleri öğrencilerin TA kullanım süresine göre anlamlı bir fark göstermekte midir?" alt probleme ilişkin bulgular ve yorumları Tablo 10'da verilmiştir.

Tablo 10. Veli Görüşlerinin Öğrencilerin TA Kullanım Süresi Değişskenine Göre Mann-Whitney U Testi Sonuçları

\begin{tabular}{|c|c|c|c|c|c|c|c|c|}
\hline Alt Ölçek & 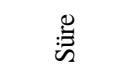 & $\mathrm{n}$ & $\begin{array}{l}\text { Sira } \\
\text { Ort. }\end{array}$ & $\begin{array}{l}\text { SiralarTo } \\
\text { p. }\end{array}$ & $\mathrm{U}$ & W & Z & $\mathrm{p}$ \\
\hline \multirow{2}{*}{ 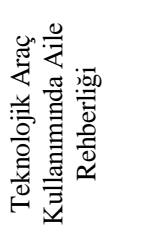 } & $\begin{array}{c}3 \text { ylldan } \\
\text { az }\end{array}$ & 120 & 157,41 & 18889,0 & \multirow{2}{*}{11629,00} & \multirow{2}{*}{18889,00} & \multirow{2}{*}{$-1,836$} & \multirow{2}{*}{,066 } \\
\hline & $\begin{array}{c}3 \text { yildan } \\
\text { fazla }\end{array}$ & 220 & 177,64 & 39081,0 & & & & \\
\hline \multirow{2}{*}{ 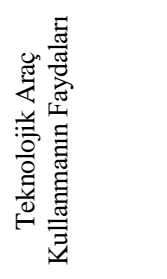 } & $\begin{array}{c}3 \text { ylldan } \\
\text { az }\end{array}$ & 120 & 158,41 & 19009,5 & \multirow{2}{*}{11749,50} & \multirow{2}{*}{19009,50} & \multirow{2}{*}{$-1,679$} & \multirow[b]{2}{*}{,093 } \\
\hline & $\begin{array}{l}3 \text { yildan } \\
\text { fazla }\end{array}$ & 220 & 177,09 & 38960,5 & & & & \\
\hline \multirow{2}{*}{ 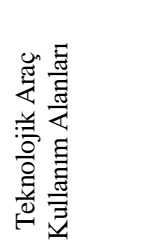 } & $\begin{array}{c}3 \text { yıldan } \\
\text { az }\end{array}$ & 120 & 151,53 & 18032,0 & \multirow[b]{2}{*}{10892,00} & \multirow[b]{2}{*}{18032,00} & \multirow[b]{2}{*}{$-2,571$} & \multirow[b]{2}{*}{, $010^{*}$} \\
\hline & $\begin{array}{c}3 \text { yıldan } \\
\text { fazla }\end{array}$ & 220 & 179,99 & 39598,0 & & & & \\
\hline \multirow{2}{*}{ 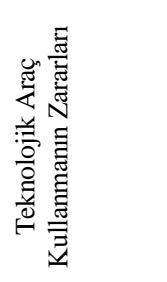 } & $\begin{array}{c}3 \text { yildan } \\
\text { az }\end{array}$ & 120 & 159,60 & 19151,5 & \multirow[t]{2}{*}{11891,50} & \multirow[t]{2}{*}{19151,50} & \multirow[t]{2}{*}{$-1,526$} & \multirow[t]{2}{*}{,127 } \\
\hline & $\begin{array}{l}3 \text { yildan } \\
\text { fazla }\end{array}$ & 220 & 176,45 & 38818,5 & & & & \\
\hline \multirow{2}{*}{ 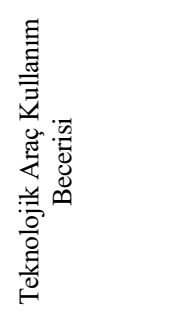 } & $\begin{array}{c}3 \text { yıldan } \\
\text { az }\end{array}$ & 120 & 163,10 & 19571,5 & \multirow{2}{*}{12311,50} & \multirow{2}{*}{19571,50} & \multirow{2}{*}{$-1,037$} & \multirow{2}{*}{,300 } \\
\hline & $\begin{array}{c}3 \text { yildan } \\
\text { fazla }\end{array}$ & 220 & 174,54 & 38398,5 & & & & \\
\hline \multirow{2}{*}{ 苛 } & $\begin{array}{c}3 \text { yildan } \\
\text { az }\end{array}$ & 120 & 152,72 & 18173,5 & \multirow{2}{*}{11033,50} & \multirow{2}{*}{18173,50} & \multirow{2}{*}{$-2,405$} & \multirow{2}{*}{, $016^{*}$} \\
\hline & $\begin{array}{c}3 \text { yildan } \\
\text { fazla }\end{array}$ & 220 & 179,35 & 39456,5 & & & & \\
\hline
\end{tabular}

Anlaml1lık düzeyi $=* \mathrm{p}<, 05$ 
Tablo 10'da Mann Whitney U Testi analiz sonuçlarına göre, TA kullanım süresi değişkeni açısından teknolojik araç kullanım alanları $[\mathrm{U}=10892,00 ; \mathrm{Z}=-2,571 ; \mathrm{p}<, 05]$ ve öneriler $[\mathrm{U}=11033,50 ; \mathrm{Z}=$ 2,405; $>$, 05] alt boyutlarında anlamlı bir fark bulunmuştur. Bu sonuçlara göre üç yıldan fazla TA kullanan öğrenciler üç yıldan az kullanan öğrencilere göre ilkokulda ders çalışma sürecinde TA'ları daha fazla kullandıkları belirlenmiştir. Üç yıldan fazla TA'ları kullanan öğrenci velilerinin bu aletleri öğrencilerin ders araştırma alanlarında kullanım önerilerinin olduğu tespit edilmiştir. Diğer dört boyutun analiz sonuçları incelendiğinde ise teknolojik araç kullanım süresi değişkeni açısından teknolojik araç kullanımında aile rehberliği $[\mathrm{U}=11629,00 ; \mathrm{Z}=-1,836 ; \mathrm{p}>, 05]$, teknolojik araç kullanmanın faydaları [U=11749,50; $\mathrm{Z}=-1,679 ; \mathrm{p}>$,05], teknolojik araç kullanmanın zararları [U= 1891,50; $Z=-1,526 ; p>, 05]$ ve teknolojik araç kullanım becerisi $[U=12311,50 ; Z=-1,037 ; p>, 05]$ alt boyutlarında velilerin düşünceleri arasında herhangi anlamlı fark bulunamamıştır.

\section{Sekizinci Alt Probleme İlişsin Bulgular}

“İlkokul çağı öğrencilerinin ders çalışma sürecinde Teknolojik Araç (TA) kullanımında veli görüşleri evde internet bağlantı durumuna göre anlamlı bir fark göstermekte midir?” alt probleme ilişkin bulgular ve yorumları Tablo 11'de verilmiştir.

Tablo 11. Veli Görüşlerinin İnternet Bağlantı Durumu Değişkenine Göre Mann-Whitney U Testi Sonuçları

\begin{tabular}{|c|c|c|c|c|c|c|c|c|}
\hline Alt Ölçek & 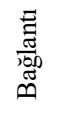 & $\mathrm{n}$ & $\begin{array}{l}\text { Sira } \\
\text { Ort. }\end{array}$ & $\begin{array}{l}\text { Siraların } \\
\text { Toplamı }\end{array}$ & $\mathrm{U}$ & W & Z & $\mathrm{p}$ \\
\hline \multirow{2}{*}{ 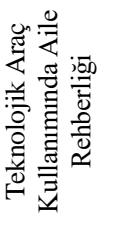 } & var & 194 & 178,83 & 34693,00 & \multirow{2}{*}{12546,00} & \multirow{2}{*}{23277,000} & \multirow{2}{*}{$-1,822$} & \multirow{2}{*}{,068 } \\
\hline & yok & 146 & 159,43 & 23277,00 & & & & \\
\hline \multirow{2}{*}{ 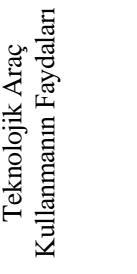 } & var & 194 & 178,49 & 34627,50 & \multirow{2}{*}{12611,50} & \multirow{2}{*}{23342,50} & \multirow{2}{*}{$-1,733$} & \multirow{2}{*}{,083 } \\
\hline & yok & 146 & 159,88 & 23342,50 & & & & \\
\hline \multirow{2}{*}{ 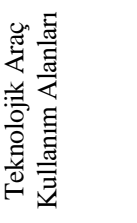 } & var & 193 & 177,39 & 34236,50 & \multirow{2}{*}{12662,5} & \multirow{2}{*}{23393,50} & \multirow{2}{*}{$-1,608$} & \multirow{2}{*}{ 108 } \\
\hline & yok & 146 & 160,23 & 23393,50 & & & & \\
\hline \multirow{2}{*}{ 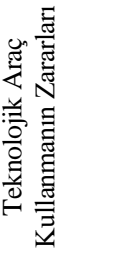 } & var & 194 & 177,07 & 34352,50 & \multirow{2}{*}{12886,5} & \multirow{2}{*}{23617,50} & \multirow{2}{*}{$-1,435$} & \multirow{2}{*}{ 151 } \\
\hline & yok & 146 & 161,76 & 23617,50 & & & & \\
\hline
\end{tabular}




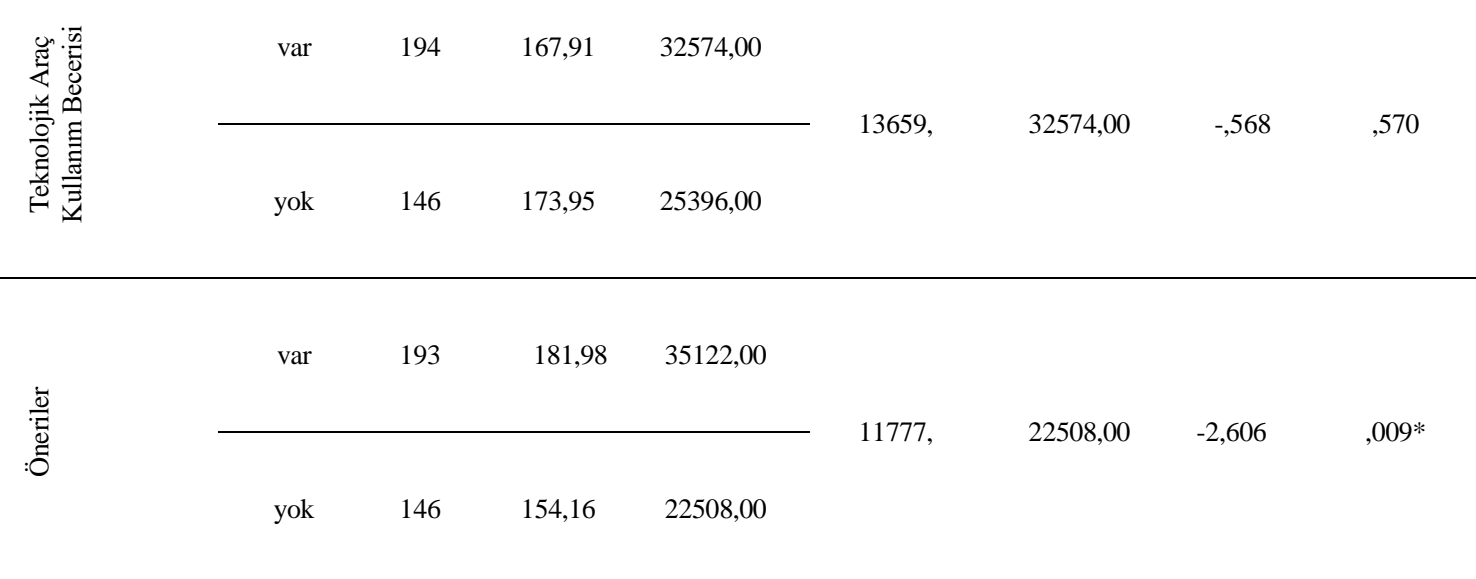

Anlamlılık düzeyi $=*_{\mathrm{p}}<, 05$

Tablo 11'de Mann Whitney U Testi analiz sonuçlarına göre, internet bağlantısı değişkeni açısından öneriler alt boyutunda anlamlı bir fark bulunmuştur [U=11777,000; $\mathrm{Z}=-2,606 ; \mathrm{p}<, 05]$. Bu sonuçlara göre evlerinde internet bağlantısı olan velilerin (Sıra ort. $=181,98)$ evlerinde internet bağlantısı olmayan velilere (Sıra ort. $=154,16)$ göre ilkokul öğrencilerinin eğitiminde TA kullanımlarının daha yoğun olduğu söylenebilir. Evlerinde internet bağlantısı olan velilerin, interneti ders çalışma süreçlerinde öğrenciler tarafından kullanılması gerektiği düşüncesini benimsedikleri söylenebilir.

Diğer beş boyutun analiz sonuçları incelendiğinde ise internet bağlantı durumu değişkeni açısından teknolojik araç kullanımında aile rehberliği $[\mathrm{U}=12546,000 ; \mathrm{Z}=-1,822 ; \mathrm{p}>, 05]$, teknolojik araç kullanmanın faydaları $[\mathrm{U}=12611,500 ; \mathrm{Z}=-1,733 ; \mathrm{p}>, 05]$, teknolojik araç kullanım alanları $[\mathrm{U}=$ 12662,500; $Z=-1,608 ; p>, 05]$, teknolojik araç kullanmanın zararları [U=12886,500; $Z=-1,435 ; p>, 05]$ ve teknolojik araç kullanım becerisi $[\mathrm{U}=13659,000 ; \mathrm{Z}=-, 568 ; \mathrm{p}>, 05]$ alt boyutlarında velilerin düşünceleri arasında herhangi anlamlı fark bulunamamıştır.

\section{SONUÇ, TARTIŞMA VE ÖNERILER}

Günümüz dünyasında teknolojide meydana gelen hızlı değişmeler bireylerin TA'ları erken yaşda kullanmaya başlamasını da beraberinde getirmiştir. Kılınç'ın yaptığı "Okulöncesi Çağındaki Çocukların Teknoloji Kullanımı Hakkında Ebeveyn Görüşlerinin İncelenmesi (2015)” adlı tez çalışmasına göre, doğdukları anda TA'lar ile tanışan öğrenciler bunun sonucu olarak çok küçük yaşta TA'ları kullanmaya başlamaktadır. Bu doğrultuda yapılan çalışmalarda; velilerin, ilkokul çağı öğrencilerinin ders çalışma süreçlerinde TA kullanımını kontrol etme eğiliminde bulundukları belirlenmiştir (Berson ve Berson, 2005).

Veliler, öğrencilerin TA kullanımının ders çalışma sürecinde faydalı olabileceğini ve TA'ların çeşitli kullanım alanlarının olduğunu düşünselerde aynı zamanda TA'ların zararlarının olduğunu belirtmektedir. Veliler, öğrencilerin TA kullanım becerisine sahip olduğu fakat kullanımının nasıl olması gerektiği hakkında yeteri kadar bilgi sahibi olmadıklarını düşünmektedir. Aktay ve Aktay (2015), tarafindan yapılan, "İlkokullarda Teknoloji Eğitimi" çalışmasında günümüzde ilkokullardaki teknoloji eğitiminin çoğunlukla yetersiz olduğu ya da teknoloji eğitimi verilmediği sonucuna ulaşılmıştır.

Türkiye ile diğer ülkeler karşılaştırıldığında özellikle gelişmiş ülkelerde tablet ve akı1lı telefon kullanım oranlarının yüksek olduğu belirlenmiştir. Bu duruma bağlı olarak da 15 yaş ve 15 yaş altı çocukların TA'lar ile etkileşimlerinin gelişmiş ülkelerde daha fazla olması doğal bir durumdur. TA'lara erişim arttıkça TA'lar ile olan etkileşim ve TA'larda harcanan süreler de artacaktır. TA'lar ile geçirilen sürenin artması TA'ları eğitimin bir parçası durumuna getirmiştir. Eğitim kavramı, öğrenme veya ihtiyaç duyulduğunda bilgiye erişme günümüzde farklılaşmış olup şu anda teknoloji tabanlı eğitime doğru bir yönelim söz konusudur. Özellikle mobil teknolojilerin yaygınlığının eğitimde bir firsata dönüştürülmesi gerekmektedir (Güler, Şahinkayası ve Şahinkayası, 2017). 
Güler ve Şahinkayası (2017) "İnternet ve Mobil Teknolojilerin Yaygınlaşması: Firsatlar ve Sınırlılıklar" adlı çalışmada Dünya ve Türkiye'deki mobil teknolojilere ve internete erişim ile bunların kullanım durumları incelenmiş; mobil bilişim teknolojilerinin eğitimde yarattığı firsatlar ve sinırlılıklar ele alınmıştır. Dünya'da ve Türkiye'de internet erişimi ve mobil teknoloji sahipliği hızlıca yaygınlaşmakta, bu teknolojilerin kullanım süresi de artmaktadır. Çoğu ülke yaşanan dijital çağın gerisinde kalmamak amacıyla bilgi üretiminde hayati role sahip internetin ve mobil teknolojilerin kullanımı ve yaygınlaşması için politikalar üretmektedir. Bu teknolojilerin eğitim alanında kullanımı için iki avantaj söz konusudur: birincisi öğrencilerin yaşanan dijital çağa adaptasyonu, bugünün TA'ları ile barışı olmaları ve geleceğin TA'larına hazır olmaları; ikincisi hâlihazırda kullanılan fakat yeterince faydalanılamayan bu TA'lardan eğitim amaçlı yararlanılmasıdır. Bu durum özellikle çok küçük yaşlara kadar inen mobil teknoloji ve internet kullanımı için eğitim alanında bir firsat arayışına yol açmaktadır. Ancak ülkemizde internet erişimi edinmeme nedenleri arasında "içerik faydasız, zararlı veya ilginç değil" düşüncesinin en yüksek orana sahiptir. Bu düşüncenin altında dijital ortamda yer alan içerik ve uygulamaların çoğunun İngilizce olması, özgün ya da ihtiyacı karşılayacak nitelikte olmaması gibi nedenler yatmaktadır. Bu sonuç doğrultusunda bakıldığında internet ve mobil teknolojilerin yaygınlığının eğitimde firsatlara dönüştürülmesi için ülkemizin ihtiyaç duyduğu ve üretilmesi gereken politikalar, yerli (Türkçe) ve uygun pedagojilerde geliştirilecek olan e-içerik ve uygulamalara yönelik olmalıdır.

Aktay ve Aktay (2015) "Illkokullarda Teknoloji Eğitimi” adlı çalışmada, ilkokullarda teknolojinin yerini belirlemeyi amaçlamıştır. Araştırmada, günümüzde ilkokullardaki teknoloji eğitiminin çoğunlukla yetersiz olduğu ya da hiç yer almadığı ortaya çıkmıştır. Bunun yanı sıra ilkokulda öğretmenlerin bir kısmı teknoloji eğitimi etkinlikleri yapmazken; bir kısmı ders etkinlikleri içerisinde teknoloji ile internetin yararları ve zararları, klavye kullanma, dosya oluşturma, ofis programları kullanımı gibi konularda eğitim verdikleri sonucuna ulaşılmıştır.

Şad ve Arıbaş (2015), tarafindan yapılan "Bazı Gelişmiş Ülkelerde Teknoloji Eğitimi ve Türkiye İçin Öneriler" çalışmasında, 'ABD, İngiltere ve Fransa gibi kalkınmış ülkelerde uygulanan eğitim programları içerisinde teknoloji öğretiminin yerinin saptaması ve Türkiye'deki mevcut durumla karşılaştırılması amaçlanmıştır. Yapılan karşılaştırmada adı geçen ülkelerin teknoloji öğretimi açısından genel bir bilinç geliştirdikleri ve eğitim sistemlerini de buna göre geliştirdikleri görülmüştür.

NTT Docomo (2015) yedi Avrupa ülkesinde (Belçika, Danimarka, İrlanda, İtalya, Portekiz, Romanya, Birleşik Kralık) ve Japonya'da çocukların mobil telefon ve internet kullanımı üzerine yapılan bir araştırmaya göre 10-12 yaş aralığında olan çocukların \%34'ünün tablet ve \%69'nun mobil telefon kullandığı anlaşılmaktadır. Yapılan çalışmada Danimarka \%60,1 oranı ile tablet ve \%93 oranı ile mobil telefon kullanımında bu ülkeler arasında en yüksek kullanım oranına sahiptir. Ayrıca mobil telefon kullanan çocukların \%71'i internete kendi cihazları üzerinden erişirken, bu oran akıllı telefonu olanlarda \%95’e kadar yükselmektedir (NTT docomo, 2015). Aynı araştırmada mobil internet kullanan çocukların \%88'i video izlemek, \%81'i sosyal ağ hizmetleri kullanmak ve \%77'si ise ders çalsşmak için mobil internetten yararlandığ 1 bulgusuna erişilmiştir. Ülkeler birbirleri ile kıyaslandığında Birleşik Krallık öğrencilerinin mobil interneti \%91 ile en çok "Ders Çalışmada" kullandıkları görülmektedir. Diğer taraftan Japonya hariç diğer ülkelerde çocukların en çok mobil interneti video izleme/yükleme ve sosyal ağ hizmetlerinde faydalanma için kullanıldığı göze çarpmaktadır. İkinci olarak, İngiltere'de yapılan bir araştırma 5-15 yaş grubu çocukların bireysel tablet sahiplikleri ve tablet üzerinden internet kullanımlarının 2014'te 2013'e göre iki katına çıktığını ve \%71'inin tablet kullandığını bildirmektedir. 515 yaş grubu için mobil telefon üzerinden internet kullanım oranının arttığı, fakat bilgisayar üzerinden giderek azaldığı bildirilmektedir. 5-15 yaş grubu içerisinde en fazla mobil telefon sahiplik oranı $\% 80$ ile 12-15 yaş grubuna aittir. 5-15 yaş grubu için 2013'te \%13 olan akıllı TV erişimi 2014'de \%39'a çıkmıştır. 5-15 yaş grubu için tablet üzerinden oyun oynama oranı artarken (2013'te \%23-2014'te \%30) diğer cihazlar üzerinden azalmaktadır (2013'te \%81- 2014'te \%77). 2014 y1lında 12-15 yaş aras1 çocuklar bir haftada TV izlemeye göre internet kullanımına daha fazla zaman harcamıştır (bir haftada 17,2 saat internet kullanımı 15,7 saat TV izleme) (Ofcom, 2014).

Atalay ve Anagün (2014), tarafindan yapılan "Kırsal Alanlarda Görev Yapan Sınıf Öğretmenlerinin Bilgi ve İletişim Teknolojilerinin Kullanımına İlişkin Görüşleri”" adlı çalışmasında, kırsalda çalışan sınıf öğretmenlerinin, öğrenme-öğretme sürecinde bilgi ve iletişim teknolojileri kullanımı ile ilgili kendi 
yeterliklerine, fiziki ortamın yeterliğine, teknolojik araç-gereç yeterliğine ve öğrenme-öğretme sürecinde bilgi ve iletişim teknolojilerinin katkısına yönelik görüşlerinin ortaya çıkarılması amaçlanmıştır. Araştırma sonucunda kırsalda görev yapan sınıf öğretmenlerinin çoğunluğunun kendini teknoloji kullanımı konusunda yeterli gördüğü ortaya konmuştur. Öğretmenlerin yarısı çalıştıkları okulun fiziki koşullarını bilgi ve iletişim teknolojileri kullanımı bakımından yeterli bulurken, diğer yarısı yetersiz olarak nitelendirmiştir. Araştırmaya katılan öğretmenler bilgi ve iletişim teknolojilerinin kullanımının öğrenmeye yönelik olarak; başarı, kolaylaştırıcılık, motivasyon, ilgi ve dikkati sağlama, anlamlı öğrenme ve zamanı etkili kullanma boyutlarında katkı sağladığını belirtmişlerdir. Araştırma sonucunda sınıf ögretmenlerinden bilgi ve iletişim teknolojileri kullanımı konusunda kendini yeterli ve yetersiz gören tüm öğretmenlerin yenilikleri izleme ve mesleki gelişime açık oldukları ortaya çıkmıştır. Bu nedenle, sınıf öğretmenlerine hizmet içi eğitimler düzenlenebilir.

Kolburan, Geçer ve Gökdaş (2014), tarafından yapılan "Öğretmenlerin Bilgi ve İletișim Teknolojilerinden Yararlanma Durumlarının Bazı Değişkenlere Göre İncelenmesi” adlı çalışmada, ilköğretim okullarında görevli öğretmenlerin bilgi ve iletişim teknolojilerini (BİT) kullanma sıklıkları, mesleki gelişimleri için bilgi edinme kaynakları ve BİT kullanımını etkileyen değişkenlerin hiyerarşik yapısı ortaya konulmaya çalışılmışıı. Araştırma sonucunda bilgi ve iletişim teknolojilerini kullanımda kıdem ve görev yapılan ilin, hizmet içi eğitim alma durumunun önemli değişkenler olduğu bulunmuştur. Katılımcıların kendilerine ait bilgisayar sahibi olma düzeylerinin genel olarak yüksek olduğu görülmektedir. "Bilgisayar kullanarak alıştırma yapma" maddesine katılımcıların çoğunlukla haftada birkaç defa seçeneğini işaretledikleri görülmektedir. "Bilgisayar kullanarak simülasyon veya deney yapma” maddesine ilişkin kullanım sıklığı düşük olmakla birlikte en yüksek kullanım sıklığı olarak ayda birkaç defa seçeneğinde yoğunlaşılmıştır. "Eğitim amaçlı bilgisayar oyunları oynama" maddesine ilişkin olarak birkaç defa seçeneğinin en çok işaretlenen madde olarak ortaya çıkması, yine eğitim yazılımları konusundaki yetersizliklerin birer yansıması olarak değerlendirilebilir. "E-posta yoluyla haberleşme" maddesine ilişkin olarak, kıdem değişkenine göre katılımcıların daha çok haftalık kullanımı tercih ettikleri görülmektedir. Yapılan kay kare testi sonucunda katılımcıların "E-posta yoluyla haberleşme" maddesine ilişkin kıdem değişkeni ile kullanım sıklıkları arasında istatistiksel olarak anlamlı bir fark olduğu belirlenmiştir. "İnternet üzerinden sohbet etme" maddesine ilişkin katılımcıların kıdem değişkenine göre yararlanma sıklıklarına bakıldığında hiç yararlanmayanların oranlarının \%38,4 ile $\% 56,6$ aralığında değişim gösterdiği belirlenmiştir. Gruplar kullanım sıklıkları bakımından en çok haftalık kullanımı tercih etmektedirler. Kıdem düzeyi azaldıkça "İnternet üzerinden sohbet etme" sıklı̆̆ının arttığı görülmektedir. Yapılan kay kare testi sonucunda "İnternet üzerinden sohbet etme" maddesine ilişkin olarak kıdem değişkeni ile kullanım sıklığı arasında istatistiksel olarak anlamlı bir fark olduğu belirlenmiştir. Genç neslin daha çok dijital ortamlarda yetişmesi ve teknolojiyle etkileşiminin daha fazla olması bu sonucun oluşmasındaki önemli faktörlerden birisi olarak değerlendirilebilir. Erkek katılımcıların, kadın katılımcılara göre daha uzun süredir bilgi ve iletişim teknolojilerini eğitsel amaçlı kullandıkları belirlenmiştir. Alan yazında da cinsiyet konusunda benzer sonuçlara ulaşılmıştır (Eroldoğan, 2007; Karaman Kurfallı, (2008). Bunun bir nedeni olarak, Deniz'in (2005), öğretmenlerin bilgisayara ilişkin tutumlarını belirlemeye yönelik araştırmasında vurgulandığı üzere cinsiyetler arasında "bilgisayara ilgi duyma" alt ölçeğinde erkek öğretmenlerin kadın öğretmenlere göre ilgilerinin daha fazla olmasından kaynaklanmış olduğu düşünülmüştür.

Sarı ve Kunt (2014), tarafından yapılan "İlkokul ve Ortaokul Öğrencilerinin Sınıf Düzeylerine Göre İnternet Kullanım Durumlarının Belirlenmesi” araştırmanın amacı, ilkokul ve ortaokul öğrencilerinin sınıf düzeylerine göre interneti kullanım amaçlarını, internetin yarar ve zararlarına ilişkin görüşlerini incelemektir. Analizler sonucunda; öğrencilerin öğrenim gördükleri sınıfın, ailenin aylık gelirinin, anne ve babanın öğrenim durumunun yükselmesine bağlı olarak evlerinde bilgisayara ve internete sahip olma durumlarında artış meydana geldiği görülmüştür. Öğrencilerin internete girecekleri adresleri belirleme konusunda en etkili kaynağın arama motorları olduğu, ailelerin ve öğretmenlerin öğrencilerin internete girecekleri adresleri bulmaları konusunda desteklerinin düşük olduğu saptanmıştır. Öğrencilerin bilgisayar kullanım amaçları arasında oyun oynamanın ve ödev için araştırma yapmanın ilk sıralarda yer aldığı belirlenmiştir.

Şen ve Gülcan (2012), tarafından yapılan "İlköğretim 4. ve 5. Sınıflarda Verilen Ev Ödevleri Konusunda Veli Görüşleri” adlı araştırmada, ilköğretim dördüncü ve beşinci sınıfta okuyan öğrenci velilerinin ev 
ödevlerine ilişkin görüşlerinin ve varsa önerilerinin betimsel yolla belirlenmesi amaç edinilmiştir. Araştırma sonuçlarına göre çocuklara ev ödevlerini yaparken çoğunlukla annelerin yardımcı olduğu ve genel olarak velilerin ev ödevlerini destekledikleri görülmüştür. Velilerin önerilerine bakıldığında; ev ödevlerinin öğrencilerin mantık yürütme, araştırma inceleme yapma, kendi başına çalışabilme, grup olarak çalıșabilme, kitap okuma alışkanlığı kazanma vb. becerilerin geliștirilmesinde katkı sağlaması gerektiğini söylemektedirler. Ayrıca veliler proje-performans ödevleri yerine, günlük ev ödevleri verilerek, öğrencilerin ödevlerini kendi kendilerine yapabilmeleri için öğretmenler tarafindan yeterli zaman ve destek sağlanması gerektiğini belirtmektedir. Veliler, çocuklar ev ödevlerini yaparken mutlaka yardım etmelerinin gerektiğini ve aynı zamanda internet kullanımının daha çok hazır ödevleri kopyalamak şekli ile olduğunu ve okullarda daha sağlılı bir değerlendirmenin yapılması gerektiğini ifade etmişdir.

Erdemir, Bakırcı ve Eyduran (2009), tarafından yapılan "Öğretmen Adaylarının Eğitimde Teknolojiyi Kullanabilme Özgüvenlerinin Tespiti” adlı çalışmanın amacı, öğretmen adaylarının öğretimde interneti, bilgisayarı ve öğretim amaçlı teknolojiyi faklı değişkenlere göre kullanabilme ve hazırlayabilme beceri düzeyleri hakkındaki görüşlerini tespit etmektir. Öğretmen adayları, interneti ve bilgisayarı öğretim amaçı kullanabilmede kendilerini yeterli görmezken, arama motorlarını kullanmada yeterli olduklarını, öğretim amaçlı basit materyalleri hazırlayabildiklerini ancak karmaşık ve çok amaçlı öğretim cihazlarını hazırlayamadıklarını belirtmişlerdir. Öğretim amaçlı teknolojiyi kullanabilme alanında özgüvenin, kadın öğretmen adaylarında erkek öğretmen adaylarına göre daha yüksek seviyede olduğu sonucuna varılmıştır. Adaylara bilgisayar ve öğretim amaçlı teknoloji kullanmayı gerektiren bireysel araştırma ve proje ödevleri ile bu özgüven farkı giderilebilir.

Karamanve Kurfallı (2008), tarafindan yapılan "Sınıf Öğretmenlerinin Bilgi ve İletişim Teknolojilerini Öğretim Amaçlı Kullanım Düzeyleri”" adlı çalışmanın amacı, yapılandırmacı yaklaşıma göre yeniden düzenlenen ilköğretim programında bilgi teknolojileri kullanımının öğretmenler tarafından uygulamaya ne derece geçirilebildiğini ortaya koymaktır. Öğretmenler bilgi teknolojilerini kullanmalarına engel olan birinci sebep olarak, bilgi teknolojilerinin kullanımında yeterli bilgi ve beceriye sahip olmadıklarını belirtmişlerdir. Ayrıca evinde ve sınıfta kullanabileceği bilgisayarı ve internet bağlantısı olan öğretmenlerin diğer öğretmenlere göre internette araştırma yapmak, eğitim CD’lerini derslerinde kullanmak gibi farklı amaçları gerçekleştirmek için bilgi teknolojilerinden daha fazla faydalandığı sonucuna ulaşılmıştır.

Yavuz ve Coşkun (2008), tarafından yapılan "Sınıf Öğretmenliği Öğrencilerinin Eğitimde Teknoloji Kullanımına İlişkin Tutum ve Düşünceleri” adlı çalışmanın amacı, ilköğretim sınıf öğretmenliği öğrencilerinin öğretimde teknolojik araç gereç kullanımına karşı tutum ve sahip oldukları fikirleri belirlemektir. Öğrencilerin öğretimde teknolojik araç gereçleri kullanmalarının, öğrencilerin tutumlarını olumlu yönde etkilediği tespit edilmiş̧ir. Yapılan görüşmeler sonucunda öğrencilerin teknoloji kullanımı hakkında olumlu fikirleri olduğu belirlenmiştir.

Velilerin, ilkokul çağı öğrencilerinin ders çalışma süreçlerinde TA kullanımı ile ilgili öğrenim düzeyine göre düşüncelerinde; TA kullanımında aile rehberliği ve TA kullanmanın zararları alt boyutunda üniversite ve lisansüstü veliler lehine anlamlı bir fark göstermektedir. TA kullanımının öğrencilerin sosyal ve duygusal gelişimleri ile bilişsel ve psikomotor gelişimlerini iyi yönde etkilediği belirtilirken, erken yaşlarda TA kullanımının öğrencilerde bazı kötü etkileri olduğu da ifade edilmiştir (Çelik, 2019; Yazar, 2015; Yetiş, 2010 ve Zorlu, 2017).

Erken yaşlarda TA kullanımının yararları ve zararları üzerinde her ne kadar eğitimciler birleşemesede ilkokul dönemindeki öğrencilerin büyük çoğunluğunun günlük yaşantılarında TA’ları kullandıkları da bir gerçektir. Öğrencilerin TA'ları kullanım şekillerinin onların karakteri ve davranışları üzerinde etkin bir rolü olduğu görülmektedir. Bu nedenle ilkokul dönemindeki öğrencilerin velilerine, TA kullanımı konusunda büyük görev ve sorumluluklar düşmektedir.

Velilerin ilkokul dönemindeki öğrencilerin TA kullanımı konusunda bir farkındalık oluşturmanın önemi üzerinde durulmaktadır. Bu nedenle velilerin ilkokul dönemindeki öğrencilerin TA kullanımına ilişkin düşüncelerinin belirlenmesine yönelik çalışmalara ihtiyaç duyulmaktadır. TA kullanımlarının öğrenciler üzerinde karar verme, problem çözme, araştırma, sorgulama, yaratıcılık, sosyal ilişkiler gibi 
yetkinliklerine yaptığı etki anlaşılır derecede görülmektedir. TA’ları hayatımızdan çıkarmamız artık neredeyse imkansız duruma gelmiştir. Günlük hayatımızın her anında faydalandığımız TA ile çok küçük yaşta tanışan öğrenciler doğru kullanım ve iyi yönlendirmeler ile öğrenim hayatlarında ilerlemeleri başarılı şekilde gösterebilirler.

Tüm bireyler için 'Eğitim, velilerin yaptıkları, öğrettikleri ve gösterdikleri ile başlar, okulun eğitimöğretim anlayışı ile devam eder.' Yargısı toplumsal kurallar çerçevesinde herkes tarafından doğru olarak kabul edilebilir. Öyle ise toplum olarak eğitimin ailede başladığı bilincindeyiz. Bu durumda doğduğu andan itibaren evde öncelikle anne sonra baba ile iletişim kuran öğrenci, TA kullanımıyla ilk kez velilerin kullandığı TA'lar aracılığı ile tanışmaktadır. Öğrencinin küçük zihinsel şemalarına, karşılaştığı TA'lar dikkat çekici gelmekte ve ilgilerini o yöne kaydırmaktadır. TA'ların dünyasına kapıldığı takdirde kaybolup gitmeye müsait olan öğrenciler TA'ları doğru ve verimli kullandıklarında geniş bir bilgi denizi ile karşılaşacaklardır.

Günümüz dünyasında teknolojik araçlar ile bilgi arasındaki etkileşimin fazla olduğu görülmektedir. Bu etkileşimi olumlu yöne çekebilen öğrencilerin ve velilerin başarıya ulaşması kaçınılmazdır. Bu yüzden öğrencilerin TA'ları nerede, nasıl ve niçin kullandıklarının üzerinde durulması gerekmektedir.

Araştırma sonuçlarına bakıldığında velilerin aile rehberliği boyutundaki söylemlere katılım durumlarının oldukça yüksek olduğu görülmektedir. Velilerin ilkokul dönemi öğrencilerinin TA'larla zaman geçirmekten ziyade ilk olarak kardeşi/kardeşleri ve arkadaşları ile oynamaya teşvik ettikleri belirlenmiştir. Bu yüzden velilerin ilkokul dönemi öğrencilerinin TA’lar kullanma vakitlerinin ölçütünü kendilerinin belirledikleri sonucuna ulaşılmıştır. Velilerin öğrencileri TA karşısında başıboş bırakmadıkları, öğrencilerin etkinliklerde kullanacakları programları ve ders başarılarını olumlu etkileyecek oyunları kendilerinin seçtiklerini ifade ettikleri görülmüştür. Velilerin TA kullanmanın zararları alt boyutundaki ifadelere katılım durumlarının yüksek olduğu saptanmıştır. Buna göre velilerin ilkokul dönemi öğrencilerinin TA'ları sık sık kullanmalarının onların arkadaşları ile olan ilişkilerini zayıflatacağına, TA'lar ile çok zaman geçirmelerinin öğrencilerin beden sağlı̆̆ını olumsuz yönde etkileyeceğine, TA kullanımının öğrencilerin sosyalleşmesinin önünde bir engel olduğuna ve TA'ları fazlaca kullanan öğrencilerin kendilerini rahat bir şekilde ifade edemeyeceklerini düşündükleri saptanmıştır.

TA kullanım şekillerinin ders başarılarına olan yansımaları bulunmaktadır. Illkokul öğrencileri, TA'lar ile faydalı kazanımların olduğu oyunlar oynamalıdır. Böylelikle hem öğrenme becerilerini geliştirmeleri hem de internet ve oyunların olumsuz yönlendirmelerinden uzaklaşmaları sağlanır. Hayatın temel taşlarının atıldığı dönemde öğrencilerin özellikle velileri tarafından yönlendirmelerinin doğru alanlara yapılması gerekmektedir.

Günümüzde öğrencileri etkileyen en büyük faktör TA kullanımının yoğunluğudur. Hayatın her alanında kullanılan TA'ların öğrenme üzerinde bir araç olduğu anlatılırsa fayda görülür. TA'lar sayesinde birçok bilgiye hızlı şekilde ulaşıldığı ve bu özelliğinin amaca ulaşmak için bir araç olarak kullanıldığı anlatılmalıdır. Öğrenciler üzerinde velilerin tutum ve davranışları etkili olmaktadır. Bu yüzden öncelikle velilerin TA kullanımını araç olarak algılaması ve bu şekilde kullanması gerekmektedir.

Veliler TA'ları sadece boş vakit etkinliklerinin değerlendirilmesi için kullanılan araçlar olarak görmekten vazgeçmelidir. TA kullanımı konusunda tam bir bilince ve yetkinliğe sahip olmayan veliler bilmeyerekte olsa öğrencileri TA bağımlısı olmaya ,az da olsa, sürüklemektedir. Bilinçsiz TA kullanımının olumsuz etkileri hemen ortaya çıkmasa bile gelecekte öğrencilerin davranışlarında ve hayata bakışlarında önemli bir etkisinin olması kaçınılmazdır.

Sonuç olarak; TA kullanımından sonra insanların kendilerine olan katkısının beraberce tartışılması sonucunda faydalı kullanımlarının arttığı görülecektir. TA'lar sayesinde üretkenliğimizin artacağı ve düşüncelerimizi kolaylıkla çevreye ulaştırabileceğimizin bilinmesi gerekmektedir. Halâ azımsanmayacak sayıda ki öğrencide TA'ları sadece boş zaman dolduran oyunların olduğu düşüncesi ön plana çıkmaktadı ve bu yüzden velilerin TA kullanımına endişe ile yaklaşımları devam etmektedir. TA kullanımlarının faydalı yönlerinin ortaya çıkması ile bu endişeler giderilebilir. Toplum olarak TA bağımlılığı yerine TA'lar ile daha üretken bir nesil nasıl olunur sorusu üzerine düşünmemiz gerekmektedir. 
1) Araştırma Türkiye'nin değişik illerinde ve daha büyük örneklem grupları üzerinde yapılarak elde edilen sonuçlar karşılaştırılabilir.

2) Araştırma nicel araştırma yöntemlerinden tarama modeline göre desenlenmiştir. Velilerin görüşlerinin derinlemesine incelenebilmesi amaciyla nitel araştırma yöntemleri kullanılarak benzer çalışmalar yapılabilir.

3) Eğitsel oyun yazılımları geliştirilip öğrencilerin TA'lar başında geçirdiği süre daha verimli hale getirilebilir.

4) Öğretmenler derse girdiği sınıfta belirli aralıklarla velilere yönelik gösteriler düzenleyerek ve velilerin bu yolla öğrenci performansı hakkında bilgilendirilmelerini sağlayarak velilerin TA'ların etkin kullanımı hakkında drama, tiyatro etkinliklerine katılmaları sağlanabilir.

5) Okullarda velileri de içine alan teknolojik araç kullanım sınıfları kurulabilir.

\section{Bilgilendirme / Acknowledgement:}

Yazarlar aşağıdaki bilgillendirmeleri yapmaktadırlar:

1- Araştırmacıların katkı oranı eșittir.

2- $\mathrm{Bu}$ çalışma Burdur Mehmet Akif Ersoy Üniversitesi Eğitim Bilimleri Enstitüsü'nde Dr. Öğr. Üyesi Feti ÇELIK danışmanlığında İbrahim FIDAN tarafından hazırlanan "İlkokul Çağı Öğrencilerinin Ders Çalışma Sürecinde Teknolojik Araç Kullanımına İlişkin Veli Görüşleri” isimli yüksek lisans tezinden üretilmiştir. Ayrıca 21-23 Ekim 2018 tarihleri Arasında, Sosyal Araştırmalar ve Davranış Bilimleri Dergisi, Kırgızistan Celal-Abad Devlet Üniversitesi ve Kazakistan Farabi Devlet Üniversitesi'nin Ev Sahipliğinde Antalya'da Düzenlenen Sadab 2.Uluslararası Sosyal Araştırmalar ve Davranış Bilimleri Sempozyumu'nda Sözlü Bildiri olarak sunulmuştur.

3- Makalenin verileri 2018 yılında toplanmış ve yorumlanmıştır.

4- Bu makalede araştırma ve yayın etiğine uyulmuştur.

\section{KAYNAKÇA}

Adıgüzel, A. (2011). Okul değişkenlerinin eğitimde verimliliğe etkisi. Düzce Üniversitesi Sosyal Bilimler Enstitüsü Dergisi, 2, 45-64.

Adıgüzel, T., Gürbulak, N. ve Sarıçayır, S. (2011). Akıllı tahtalar ve öğretim uygulamaları. Mustafa Kemal Üniversitesi Sosyal Bilimler Enstitüsü Dergisi, 8(15), 457-472.

Akbulut, Y. (2013). Çocuk ve ergenlerde bilgisayar ve internet kullanımının gelişimsel sonuçları. Trakya Üniversitesi Eğitim Fakültesi Dergisi, 3(2), 53-68.

Akpınar, Y. (2005). Bilgisayar destekli eğitimde uygulamalar. 2. Baskı. Ankara: Anı Yayıncılık.

Aktay, S. ve Güven Aktay, E. (2015). İlkokullarda teknoloji eğitimi. Adryaman Üniversitesi Sosyal Bilimler Enstitüsü Dergisi, 8(19), 17-44.

Aksoy, H. H. (2003). Uluslararası karşılaştırma ölçütlerinin kullanımı ve Türkiye. Eğitim Bilim Toplum Dergisi, 1(1), 51-60.

Alkan, C. (1998). Eğitim teknolojisi: disiplin, kuram, süreç, ortam, uzman, uygulama. Ankara: An1 Yayincilik.

Alkan, C. (1998). Eğitim teknolojisi. Ankara: Anı Yayıncılık.

Alkan, C. (2011). Eğitim teknolojisi. 8. Baskı. Ankara: Anı Yayıncılık.

Alpar, D., Batdal, G. ve Avcı, Y. (2007). Öğrenci merkezli eğitimde eğitim teknolojileri uygulamaları. Banan Ali Yücel Eğitim Fakültesi Dergisi, 7(1), 19-31. 
Altan, T. ve Tüzün, H. (2011). Teknoloji-zengin bireysel öğrenme ortamlarının fatih projesindeki yeri akademik bilişim. 11-13. Akademik Bilişim Konferansı Bildirileri, 2-4 Şubat 2011 İnönü Üniversitesi, Malatya.

Altun Akbaba, S. ve Çakan, M. (2008). Öğrencilerin sınav başarısına etki eden faktörler: LGS/ÖSS sınavlarındaki başarılı iller örneği. İlköğretim Online, 7(1), 157-173.

Arıbaş, S. ve Şad, N. S. (2010). Bazı gelişmiş ülkelerde teknoloji eğitimi ve Türkiye için öneriler. Bu Çalışma, 01-03 Eylül 2008'de Sakarya'da Düzenlenen 17. Ulusal Eğitim Bilimleri Kongresinde Sunulan "Kalkınmış Ülkelerde ve Türkiye'de Teknoloji Öğretimi” başlıklı Çalışmanın Geliştirilmiş Halidir. Milli Eğitim, (185), 278-299.

Aslanargun, E. (2007). Okul - aile işbirliği ve öğrenci başarısı üzerine bir tarama çalışma. Sosyal Bilimler Dergisi , 9(18), 119-135.

Ata, B., Altun, A., Avcı, E., Er, H. ve Öztürk, T. (2010). Bilim teknoloji ve sosyal değişme. 3. Baskı. Ankara: Pegem Akademi Yayıncılık.

Atalay, N. ve Anagün Ş. S. (2014). Kırsal alanlarda görev yapan sınıf öğretmenlerinin bilgi ve iletişim teknolojilerinin kullanımına ilişkin görüşleri. Eğitimde Nitel Araştırmalar Dergisi - Journal of Qualitative Research in Education, 2(3), 9-27.

Avc1, Y. ve Nazlı, S. (2005). Sınıf rehberliği etkinliklerinin öğrencilerin verimli ders çalışma alışkanlıkları, akademik başarıları ve sınav kaygıları üzerindeki etkisi. BAÜ Sosyal Bilimler Dergisi, 7(11), 135-152.

Balcı, A. (2015). Sosyal bilimlerde araştırma: yöntem teknik ve ilkeler. 11. Baskı. Ankara: Pegem Yayınları.

Bayraktar, N. (2017). Teknoloji nedir? önemi, faydalarl ve zararlarl. 29 Mayıs 2019 tarihinde https://paratic.com/teknoloji-nedir/ adresinden erişildi.

Beder, A. (2015). Ortaokul öğrencilerinin güvenli internet kullanım durumlarının belirlenmesi. Yayımlanmamış yüksek lisans tez, Afyon Kocatepe Üniversitesi, Afyon.

Berson, I., Berson, M. (2005). Challenging online behaviors of youth: findings from a comparative analysis of young people in the US and New Zealand. Social Science Computer Review, 23(1), 2938.

Büyüköztürk, Ş., K1lıç Çakmak, E., Akgün, Ö. E., Karadeniz, Ş. ve Demirel, F. (2008). Bilimsel araştırma yöntemleri. Ankara: Pegem Akademi.

Çamlıbel Çakmak, Ö. (2010). Okul öncesi eğitim kurumlarında aile katılımı. Abant İzzet Baysal Üniversitesi Sosyal Bilimler Enstitüsü Dergisi, 20, 1-18.

Çiftçi, S., Taşkaya, S. M. ve Alemdar, M. (2013). Sınıf öğretmenlerinin Fatih projesine ilişkin görüşleri. Illkögretim online, 12(1), 227-240.

Demir, Ö. (2013). Öğretmen adaylarının ders çalışma sırasında bilişsel farkındalık becerilerini kullanma düzeylerinin incelenmesi: Nitel bir çalışma. Hacettepe Üniversitesi Eğitim Fakültesi Dergisi, 44, 133-148.

Demirezen, S. ve Akhan, N. E. (2013). İlköğretim öğrencilerinin ders çalışma üzerine algıları. Karadeniz Sosyal Bilimler Dergisi, 5(8), 169-183.

Duru, S. ve Çöğmen, S. (2017). İlkokul ve ortaokul öğrencileri ile velilerin ev ödevlerine yönelik görüşleri. IIlköğretim Online, 16(1), 354-365.

Ekinci Vural, D. ve Kocabaş, A. (2016). Okul öncesi eğitim ve aile katılımı. Electronic Journal Of Social Sciences, 59(15), 1174-1185.

Erdemir, N., Bakırcı, H. ve Eyduran, E. (2009). Öğretmen adaylarının eğitimde teknolojiyi kullanabilme özgüvenlerinin tespiti. Türk Fen Eğitimi Dergisi, 6(3), 99-108. 
Göç, B. (2019). Teknolojinin zararları ve yararları çocuklar için. 02 Haziran 2019 tarihinde https://www.mentalup.net/blog/teknolojinin zararlari ve yararlari adresinden erişildi.

Güler, H., Şahinkayası, Y. ve Şahinkayası, H. (2017). İnternet ve mobil teknolojilerin yaygınlaşması: Firsatlar ve Sinırllliklar Sosyal Bilimler Dergisi, 7(14), 187.

Gültekin, M. ve Kılıç, Z. (2014). İlköğretimde çocuğu olan ailelerin çocuklarının eğitim ve öğretiminde karşılaştıkları sorunlar ve eğitim gereksinimleri. Türkiye Sosyal Araştırmalar Dergisi, 182(182), 85-112.

Güvenç, H. (2010). Ders çalışma özyeterlik algısı ölçeği'nin geliştirme çalışması. Yüzüncü Yıl Üniversitesi Eğitim Fakültesi Dergisi, 7(1), 59-69.

Karaman, K. M. ve Kurfallı, H. (2008). Sınıf öğretmenlerinin bilgi ve iletişim teknolojilerini öğretim amaçlı kullanım düzeyleri. Kuramsal Eğitim Bilim, 1(2), 43-56.

Karasar, N. (2000). Bilimsel araştırma yöntemi. Ankara: Nobel Yayın Dağıtım.

Kenar, İ. (2012). Teknoloji ve derslerde teknoloji kullanımına yönelik veli tutum ölçeği geliştirilmesi ve tablet pc uygulaması. Eğitim Bilimleri Araştırmaları, 2(2), 123-139.

Demirel, Ö. (2003). Kuramdan uygulamaya eğitimde program geliştirme.Ankara: Pegem Yayıncılık.

Khasawneh, O. M., ve Al-Awidi, H. M. (2008). The effect of home computer use on jordanian children: a parental perspective. Journal of Educational Computing Research, 39(3), 267-284.

Kılınç, S. (2015). Okulöncesi çağındaki çocukların teknoloji kullanımı hakkında ebeveyn görüşlerinin incelenmesi. Yayımlanmamış yüksek lisans tezi, Kütahya Dumlupınar Üniversitesi Eğitim Bilimleri Enstitüsü, Kütahya.

Kolburan-Geçer, A. ve Gökdaş, İ. (2014). Öğretmenlerin bilgi ve iletişim teknolojilerinden yararlanma durumlarının bazı değişkenlere göre incelenmesi. Eğitim Bilimleri Araştırmaları Dergisi, 4(1), 89112.

Küçükahmet, L. (2009). Program geliştirme ve öğretim. Ankara: Nobel Yayın Dağıtım.

MEB (2003). İlköğretim kurumları yönetmeliği. 27/08/2003 Tarihli 25212 Say11 Resmi Gazete.

Milli Eğitim Bakanlığı (MEB), (2004). Illköğretim fen ve teknoloji dersi (4-5. Sinıflar) Öğretim Program. Ankara: Devlet Kitapları Müdürlüğü Basımevi.

Murphy, C. ve Beggs, J. (2003). Primary Pupils and teachers use of computers at home and school. British Journal Of Educational Technology, 34(1), 79-83.

Odabaşı, H. F., Kabakçı, I. ve Çoklar, A. N. (2007). Internet, çocuk ve aile. 2. Baskı. Ankara: Nobel Yayıncilik.

Özçiftçi, M. ve Çakır, R. (2015). Öğretmenlerin yaşam boyu öğrenme eğilimleri ve eğitim teknolojisi standartları özyeterliklerinin incelenmesi. Eğitim Teknolojisi Kuram ve Uygulama, 5(1), 1-19.

Özen, H. Güleş, H. ve Aypay, A. (2012). İlköğretim okulu öğrencilerinin okula, aileye ve sosyal çevreye ilişkin değer yargıları. Eğitim ve İnsani Bilimler Dergisi: Teori ve Uygulama, 3(6), 51-74.

Sakarya, S., Tercan, İ. ve Çoklar, A. N. (2011). İlköğretim öğrencilerinin interneti ve arama motorlarını kullanma durumlan. $5^{\text {th }}$ International Computer Instructional Technologies Symposium, 22-24, September, Firat Üniversitesi, Elazığ.

Sarı, S. ve Kunt, H. (2015). İlkokul ve ortaokul öğrencilerinin sınıf düzeylerine göre internet kullanım durumlarının belirlenmesi. Dumlupınar Üniversitesi Sosyal Bilimler Dergisi, (40), 0-0.

Seferoğlu, S. S. (2008). İlköğretim okullarında teknoloji kullanımı: yaşanan sorunlar, gözlemler ve çözüm önerileri. Eğitimde Küreselleşme ve Bilişim Teknolojileri I. Uluslararası Konferansı Bildiriler Kitabı. 45-53. Bakü, Azerbaycan. 
Seferoğlu, S.S., Akbıyık, C. ve Bulut, M. (2008). İlköğretim öğretmenlerinin ve öğretmen adaylarının bilgisayarların öğrenme/öğretme sürecinde kullanımı ile ilgili görüşleri. Hacettepe Üniversitesi Eğitim Fakültesi Dergisi, 35, 273-283.

Sevinç, M. (2006). Evrensel ve yerel değerlerin ĕgitime yansımalarl, küreselleşme ahlak ve değerler. (Ed. Yurdagül Mehmedoğlu ve Ali Ulvi Mehmedoğlu). İstanbul: Litera Yayınc1lık.

Sönmez, V. (2007). Öğretim ilke ve yöntemleri. Ankara: Anı Yayıncılık.

Sünbül, A. M. (2008). Eğitime yeni bakışlar. 3. Baskı. Eğitim Akademi Yayınları.

Şad, N. ve Arıbaş, S. (2010). Bazı gelişmiş ülkelerde teknoloji eğitimi ve Türkiye için öneriler. Malatya İnönü Üniversitesi Eğitim Fakültesi Dergisi, 40(185), 278-299.

Şahinkayası, H. ve Şahinkayası, Y. (2004). Bilgisayar ve öğretim teknolojileri eğitimi (böte) bölümü lisans programında bulunan "öğretim teknolojileri ve materyal geliştirme" dersinin analizi. XIII. Ulusal Eğitim Bilimleri Kurultayl, 6-9 Temmuz 2004 İnönü Üniversitesi, Eğitim Fakültesi, Malatya.

Şen, H. Ş. ve Gülcan, M. G. (2014). İlköğretim 4. ve 5. sınıflarda verilen ev ödevleri konusunda veli görüşleri. Dumlupinar Üniversitesi Sosyal Bilimler Dergisi, 29, 29-41.

Şenol, Ş. (2012). Araştırma ve örnekleme yöntemleri. 1. Basım. Ankara: Nobel Akademik Yayıncılık.

Şimşek, N. (1997). Derste eğitim teknolojisi kullanımı. 2. Baskı. Ankara: Nobel Yayın Dağıtım.

Şimşek, N. (2002). Derste eğitim teknolojisi kullanımı. Ankara: Nobel Yayın Dağıtım.

Yavuz, S. ve Coşkun, A. E. (2008). Sınıf öğretmenliği öğrencilerinin eğitimde teknoloji kullanımına ilişkin tutum ve düşünceleri. Hacettepe Üniversitesi Eğitim Fakültesi Dergisi, 34, $276-286$.

Y1ldırım, A., Doğanay, A. ve Türkoğlu, A. (2000). Okulda başarı için ders çalışma ve öğrenme yöntemleri. Ankara: Seçkin Yayınları.

Yıldırım, A. ve Şimşek, H. (2008). Sosyal bilimlerde araştırma yöntemleri. Ankara: Seçkin Yayınları.

Yıldız, N., Akbulut, Ö. ve Bircan, H. (2002). Ki-Kare ve Kolmogorov-Smirnov uygunluk testlerinin simulasyon ile elde edilen veriler üzerinde karşılaştırılması. 3. Baskı. Erzurum: Şafak Yayınları. 